\title{
Ecology of Munida gregaria (Decapoda, Anomura): distribution and abundance, population dynamics and fisheries
}

\author{
John R. Zeldis* \\ Portobello Marine Laboratory, University of Otago, Dunedin, New Zealand
}

\begin{abstract}
Pelagic larvae, postlarvae and benthic adults of the galatheid crab Munida gregaria (Fabricius 1793) occur along the continental shelf of the east coast of the South Island and around the subantarctic islands of New Zealand. In the south-eastern South Island, larvae appear in June or July and develop through 5 zoeal stages. As they age, the larvae accumulate inshore and north of the Otago Peninsula. Following metamorphosis in October, the pelagic postlarvae shoal through the summer prior to settlement to the bottom. The length of the shoaling period can vary considerably from year to year, ranging from a few weeks to 6 mo or longer. The pelagic postlarvae are very patchy in spatial distribution. Postlarval biomass, as determined by aerial surveys along the south-east coast, was highest along the inner to middle shelf from Blueskin Bay to Moeraki, immediately north of the Otago Peninsula. Benthic settlement was also heavier in this area relative to south of the Peninsula. This provides evidence that a meso-scale eddy interrupts the northward drift of larvae and postlarvae in the Southland Current and retains them near the upstream boundary of the benthic population. In the Otago Peninsula area substantial benthic recruitment occurred only when and where the density of older cohorts on the bottom was low. After relatively long shoaling periods the 1976-1978 cohorts settled on inner shelf sands and migrated to middle and outer shelf bryozoan-covered bottoms within a few months. In contrast, after relatively brief shoaling periods the 1979 and 1980 cohorts settled directly on the middle and outer shelf bryozoan area which was vacant due to high mortality in previously dense older cohorts. It is proposed that density dependent regulation of $\mathrm{O}+$ cohort settlement by older cohorts occurs, possibly by a combination of cannibalism and non-lethal agonistic behaviour. In the absence of these effects, settlement occurs early, accounting for the short or non-existent shoaling seasons observed each 3 to $5 \mathrm{yr}$ in a $30 \mathrm{yr}$ record. There is presently consideration of a fishery for pelagic $M$. gregaria in New Zealand, primarily for use as food stock for cultured salmon. Because the density of newly settled $\mathrm{O}+$ animals was nearly maximal by the end of January each year, pelagic animals remaining after that time could be fished without seriously affecting replenishment of the benthic stock. Available biomass would be highly variable and probably non-existent once each 3 to 5 yr. This exploitable 'surplus' is important in the marine food web so such a fishery would need careful consideration.
\end{abstract}

\section{INTRODUCTION}

The family Galatheidae (squat lobsters) is represented by more than 200 species, almost exclusively benthic as adults, which range from sublittoral to abyssal depths. A few of these occur in abundance (Benedict 1903) and 2, Pleuroncodes monodon (Milne Edwards 1891) and Cervimunida johni Porter, support a benthic trawl fishery off the Chilean coast (Longhurst

\footnotetext{
- Present address: Fisheries Research Division, N.Z. Ministry of Agriculture and Fisheries, Box 297, Wellington, New Zealand
}

1967a, Castilla \& Becerra 1976). Only 2 species, $P$. planipes Stimpson and Munida gregaria (Fabricius), are pelagic in their postlarval lives when they often occur in massive swarms before settling to the bottom. $P$. planipes occurs off Baja California and Southern California and its various ecological aspects have been described by Boyd (1967), Longhurst (1967a, b, 1968), Longhurst et al. (1967), Blackburn (1969), Blackburn \& Thorne (1974) and Kato (1974). M. gregaria occurs off Patagonia, Tierra del Fuego and the Falkland Islands where it has been the subject of two Discovery Reports by Matthews (1932) and Rayner (1935) as well as off Tasmania in Bass Strait (Henderson 1888). It also 
occurs off eastern New Zealand and its subantarctic islands, and various aspects of its biology have been reported by Thomson (1898), Thomson \& Thomson (1923), Young (1925), Roberts (1973), Williams (1973, 1980), Jillett (1976) and Zeldis \& Jillett (1982).

In continental shelf waters of south-eastern New Zealand, Munida gregaria larvae first appear in midwinter, and subsequently pass through 5 larval stages until postlarval metamorphosis in spring. The pelagic postlarvae shoal over summer, during which time adult features are wholly or partly acquired. They then settle to the bottom where they may live for 2 to $3 \mathrm{yr}$ and spawn up to 3 times. The duration of the postlarval shoaling phase can vary considerably from year to year, and this has subtle but important effects on the eventual morphology of the adults (Williams 1973). These characteristics confused taxonomic study of the species (Matthews 1932) because some benthic specimens had been collected that did not have the features originally described for $M$. gregaria by Fabricius. From these specimens the species Munida subrugosa (White) was created. M. gregaria was most commonly collected from the pelagic habitat and considered by some to be merely the young stage of $M$. subrogosa. Confusion arose because large $M$. gregaria were occasionally collected on the bottom and in sizes up to 3 times that of $M$. subrugosa. Williams (1973) kept pelagic individuals in the laboratory to observe their subsequent development. She found that when a pelagic animal settles to the bottom, its morphology gradually changes over a series of moults until it conforms to the description of $M$. subrugosa. $M$. gregaria and $M$. subrugosa are, therefore, the same species (by priority $M$. gregaria)'. Plate 1 in Williams (1973) shows the differences between these 2 morphs. Subsequent work by Williams (1980) showed that changes also occur in the chemical composition of the body, such that the density of the crab relative to seawater increases markedly in post-settlement. After adopting 'benthic' features, postlarvae are not seen in surface samples and can be considered permanent members of the benthos. If, however, they remain pelagic for an extended period, they may grow to a large size, retaining pelagic morphology as benthic adults (Williams 1980). Thus, the variation in morphology of $M$. gregaria individuals can be used to trace the timing of benthic recruitment of individuals or of entire year classes.

The population dynamics of Munida gregaria in New Zealand have not previously been studied. $M$. gregaria abundance, however, and its importance as food for a myriad of marine fish, bird and mammal species has often been noted (Thomson \& Thomson 1923, Young 1925, Graham 1939, Dawbin 1954). Recently, there has also been interest in utilizing pelagic $M$. gregaria as food stock for cultured salmonids in New Zealand. Kato (1974) has discussed the development of a fishery on the pelagic phase of Pleuroncodes planipes in Baja California, for use in the diet of pen-reared Pacific Salmon. As well as providing a good source of protein, it was discovered that the crabs provided carotenoid pigments which gave the fish flesh its natural reddish tint. Possibilities also exist in their use for human consumption. Kato gave information on chemical composition and on fishing methods for pelagic red crabs. He considered that in areas where crabs were concentrated, catch rate is limited only by the size of the gear a vessel can handle. An example catch rate of up to 20 tons $\mathrm{h}^{-1}$ with a 50 foot $(16.7 \mathrm{~m})$ midwater trawl was given.

The present study describes the distribution of pelagic (larval, postlarval) and benthic (adult) Munida gregaria around New Zealand and then considers in detail the distribution and abundance of pelagic and benthic animals on the south-eastern New Zealand continental shelf over a number of years. Both life stages are then considered in a description of $M$. gregaria population dynamics, particularly with respect to the relation of adult stock to recruit abundance. This relation is important because it provides an understanding of the natural changes in abundance which inevitably occur so that these may be distinguished from the effects of overfishing ... (Thompson 1926). The study also describes biomass available to a fisheгу for pelagic $M$. gregaria and rationale for its management.

\section{METHODS}

\section{Pelagic phase distribution and abundance}

Information on the New Zealand-wide distribution of the pelagic postlarval phase of Munida gregaria was gathered from collections of the National Museum, Wellington and observations by staff of Fisheries Research Division and Fisheries Management Division, Ministry of Agriculture and Fisheries. Use was also made of fishermen and lighthouse keepers along the east coast of the South Island as observers during the postlarval seasons of 1979-1980 and 1980-1981. Fishermen were asked to record the presence or absence of postlarvae in the area steamed on each day. Lighthouse keepers were asked to record presence or absence of $M$. gregaria daily.

In south-eastern New Zealand, the distribution and abundance of pelagic Munida gregaria were studied in various ways. Williams (1980, Fig. 1) presented data on the daily occurrence of pelagic postlarvae as seen from the Portobello Marine Laboratory (PML) wharf from 1953 to 1970 . This series has been extended until 1982 
Table 1. Specifications of nets used in this study

\begin{tabular}{|lcccc|}
\hline Net type & Fixed net & Larval net & Postlarval net & Dip net \\
Shape & rectangular & cylinder-cone & cylinder-cone & cone \\
Towing speed $(\mathrm{kts})$ & tidal velocity & 2.5 & 2.5 & 2.5 \\
Mean Vol. filtered $\left(\mathrm{m}^{3}\right)$ & 400 & 200 & 600 & 1.1 \\
Mouth area $\left(\mathrm{m}^{2}\right)$ & 0.25 & 0.25 & 1.0 & 0.12 \\
Mesh size $(\mathrm{mm})$ & 1.0 & 0.37 & 9.50 & 2.50 \\
Mean filtration & - & $75.3 \pm 6.7$ & $91.5 \pm 6.4$ & - \\
efficiency $(\%)$ & & & \\
\hline
\end{tabular}

(except December to October 1977 when no records were kept) in the present study.

Seasonality and succession of larval and postlarval stages were studied by taking zooplankton samples from the $4 \mathrm{~m}$ deep channel below the PML wharf in the current of the flood tide. A fixed net (Table 1) fitted with a flowmeter (General Oceanics) was fished over the first $3 \mathrm{~h}$ of the $6 \mathrm{~h}$ flood tide. The net fished from the surface to $1 \mathrm{~m}$ depth as the tide rose. Over this period it was expected that water that was recently outside the harbour would be filtered because of the short, $2 \mathrm{~d}$ residence time of water in the lower harbour (Quinn 1978). Sampling started each year when benthic animals first became berried and covered the larval and postlarval seasons from 1977-1981. Samples were taken day or night as this does not affect larval abundance (Brough 1979). They were subsampled using a
Folsom plankton splitter. At least 50 larvae from subsamples were staged (Roberts 1973); in samples where larvae were rare, either the whole sample or a large subsample of it was examined.

The spatial distribution of larval stages was studied using samples obtained in a fish egg survey done in August 1971 by Robertson (1980). The survey was done on 10 transects of stations across the continental shelf from Nugget Point to Moeraki. Samples were taken with a $1 / 4 \mathrm{~m}^{2}$ net towed at 0 to $1 \mathrm{~m}$ depth for $0.5 \mathrm{~h}$. Only night-collected samples were used. Samples were analysed as described above.

The time-space distributions of larvae and postlarvae were studied through the spring and summer from 1978 to 1981 on a 6 station transect across the continental shelf east of the Otago Peninsula (Fig. 1). Two nets were used (Table 1), one for larvae and a larger one for

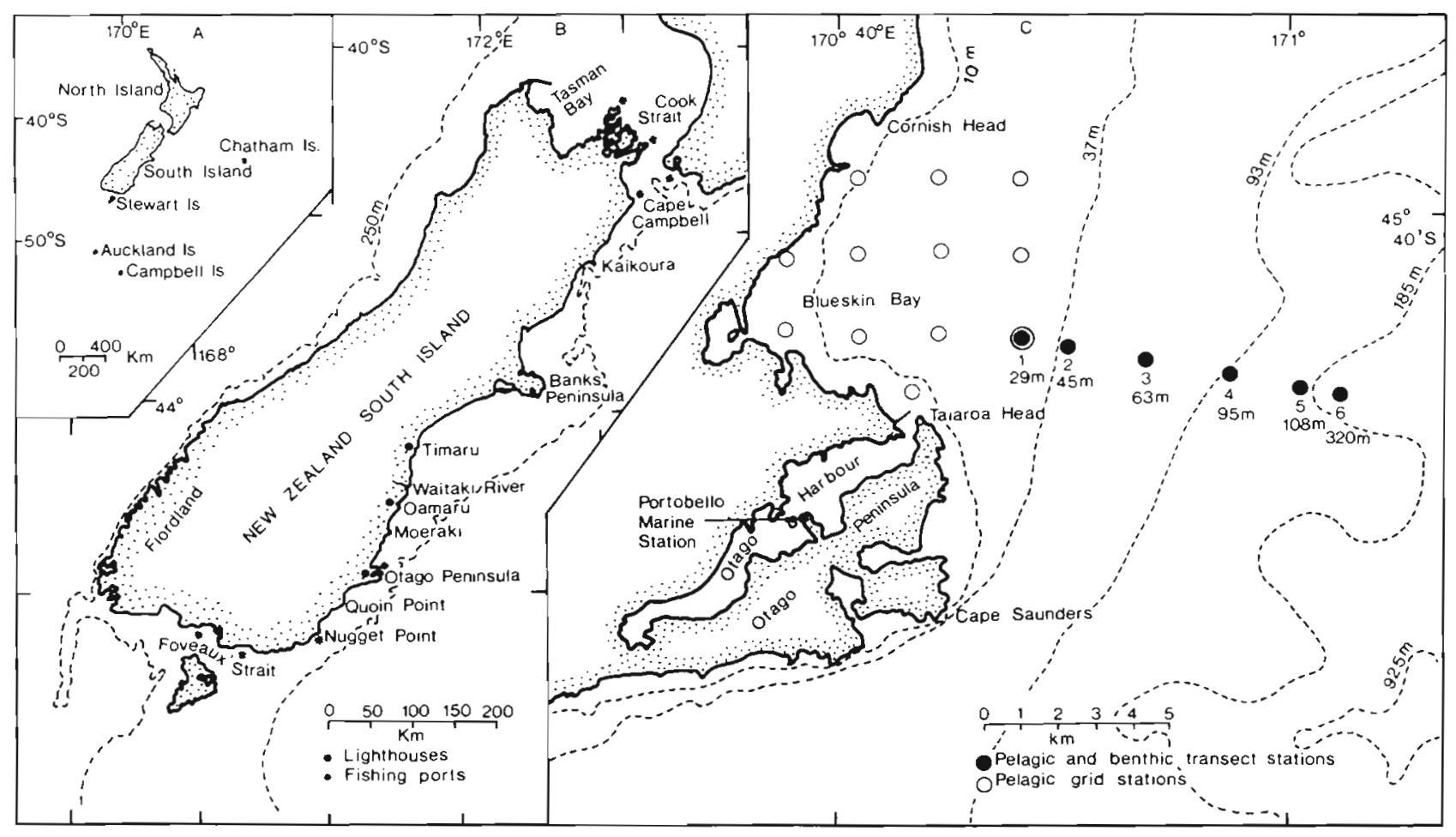

Fig. 1. Place names and sampling locations used in this study 
faster swimming postlarvae. The nets were fitted with internal and external TSK flowmeters in the recommended positions (Tranter \& Heron 1968). They were fished obliquely using a Scripps depressor from the surface to within $5 \mathrm{~m}$ of the bottom (10 $\mathrm{m}$ on deeper tows) but only to $100 \mathrm{~m}$ at $\operatorname{Stn} 6$. Net depth was determined with a bathykymograph and/or by wire angle. The larval net was used while wharf samples showed larvae to be present in coastal waters and the postlarval net was used following the disappearance of larvae and the appearance of the newly metamorphosed postlarvae. Samples were analyzed as described above.

To study the spatial distribution of postlarvae in more detail all or part of a grid of stations in Blueskin Bay (Fig. 1) was surveyed 8 times during summer 1978-1980. The postlarval net was fished obliquely as described above. A histogram of catch size vs. frequency was plotted. The catch sizes were then transformed to $\log _{10}(X+1)$ and the resultant frequency distribution was tested for departure from normality (skewness and kurtosis) by the methods described in Pearson \& Hartley (1962). If the transformed data approximated a normal frequency distribution, they were considered indicative of overdispersion or patchiness in the sampled population (Cassie 1963). Geometric mean densities (Sokal \& Rohlf 1969) were calculated for each survey date and for all the surveys combined.

Distribution and biomass of postlarvae were studied from aircraft during 10 flights made from 1978 to 1982 . Flights were made in December through April when pelagic postlarvae were known to occur. They were made on clear mornings with little wind. General methods used in these surveys were given in Zeldis \& Jillett (1982). Quantitative biomass estimations using vertical photographs were made by projecting slides onto a screen divided into $3,7501 \mathrm{~cm}^{2}$ squares and counting the number of squares occupied by shoals. The area in each square was calculated on the basis of aircraft altitude and the focal length of the lens used. The number of Munida gregaria was then estimated by assuming that the photographed shoals were $1 \mathrm{~m}$ thick and each $\mathrm{m}^{3}$ of shoal contained 2,705 individuals (estimated from the aimed dip net surveys) (see below). The wet weight of 2,705 individuals was estimated for each flight date by substituting mean postlarval carapace length values determined from samples collected within a few days of the flights into a regression " of carapace length versus wet weight.

Because Munida gregaria are extremely patchy in their spatial distribution (Zeldis \& Jillett 1982), aimed

\footnotetext{
- This regression was determined from samples collected in 1980-81; wet weight $(\mathrm{mg})=2,811 \cdot 10^{-4}$; carapace length $(\mathrm{mm})^{2 \cdot 989} ; \mathrm{r}=0.957 ; \mathrm{n}=180$
}

plankton tows were used to allow biomass estimations from aerial photographs. These were done in 2 ways: (1) Aimed horizontal plankton tows were made using the postlarval net on 2 occasions in March 1981 when shoals were abundant in the Taiaroa Head area Although these were aimed as accurately as possible at dense surface shoals, underestimation was inevitable due to considerable (and variable) amounts of towing distance spent outside shoals. (2) Aimed samples were taken from shoals using a hand-held dip net (Table 1) which was attached to a $3 \mathrm{~m}$ long pole and had a flowmeter (General Oceanics) suspended across its mouth. This was used while the vessel passed slowly through a shoal thereby overcoming the problem of net accuracy. This method was used on one occasion on a day when shoals were also sampled using the postlarval net method.

The numbers of postlarvae caught by the 2 methods were determined volumetrically. Departures from normality of $\log _{10}$ transformed data were tested and geometric mean densities were calculated as for the grid surveys.

There are a number of unquantified sources of error involved with the aerial biomass estimates. The use of some slightly oblique photographs and the inability to photograph all shoals sighted (especially on 25 Jan 79) caused some underestimation of shoal area which could be intuitively placed at about $25 \%$. Also, the shoal thickness estimate of $1 \mathrm{~m}$ may have been inaccurate in some instances. Dense Munida gregaria shoals, however, were usually 0.5 to $2.0 \mathrm{~m}$ thick as seen during many hours at sea. Shoal density (no $M$. gregaria $\cdot \mathrm{m}^{-3}$ ) could also have varied significantly from the aimed dip net estimate. Error due to the latter two sources could be intuitively placed at a maximum of $200 \%$, although it would be expected that the actual error would tend toward a mean somewhere between plus or minus $200 \%$

\section{Benthic phase distribution and abundance}

Information on the New Zealand-wide distribution of benthic Munida gregaria was gathered from collections of the New Zealand Oceanographic Institute (NZOI) and from collections of the National Museum, Wellington. Because samples were taken using various methods, results are presented on a presence-absence basis only.

In south-eastern New Zealand samples of benthic Munida gregaria were taken at 6 stations on a transect across the continental shelf off the Otago Peninsula (Fig. 1). The stations covered a gradation of depth from the inner shelf (Stn. 1 and 2), to the middle shelf (Stn. 3 and 4), and the outer shelf and upper slope (Stn. 5 and 
6). They were occupied approximately every $6 \mathrm{wk}$ from May 1978 to March 1981. Samples were obtained by hauling a box dredge which had a mouth width of $110 \mathrm{~cm}$ and a steel mesh size of $5 \mathrm{~mm}$. The dredge was designed to sample epibenthic fauna and a superficial layer of the substratum. It was fitted with weighted doors across its mouth which swung shut to prevent pelagic $M$. gregaria from contaminating the catch while shooting and retrieving. The doors were swung open by outriggers when the dredge started moving across the bottom. Standard practice was to dredge for $5 \mathrm{~min}$ at $600 \mathrm{rpm}$ on the course of the transect. This course was normal to the prevailing north-easterly set of the Southland current, thus variability in dredge velocity over the bottom caused by between sample variation in current velocity should have been minimized. Close-up photographs were taken of the dredge contents to identify living and dead macrofaunal components of the sampled sediments

If the Munida gregaria sample was larger than approximately 150 individuals, a random subsample of 100 to 150 individuals was taken. Males were identified by presence of copulatory pleopods. Carapace length was measured using a binocular microscope as the distance from the posterior mid-dorsal edge of the carapace to the tip of the rostrum. For most samples an assessment of morphological type (Williams 1973) was made for crabs greater than $15 \mathrm{~mm}$ carapace length for use in cohort analysis (below).

Length-frequency histograms were constructed using data pooled from the shelf stations (Stn. 1 to 5) to maximize sample size. Pooling was justified by the similarity in length modes at Stations 1 to 5 on each sample date (Zeldis 1983). The slope station (Stn. 6) was excluded from this analysis because it was not occupied consistently through the study period. Cohort analysis of the samples was done using the following criteria: (1) Locations of minima in the length-frequency histograms; (2) Morphology of the crabs. This was used to isolate individuals spawned in 1976 which retained 'pelagic' morphology (see below and Williams 1980) through the study period. Female and male cohort densities were contoured using sample date and station location as coordinates. Densities were transformed to $\log _{10}(X+1)$ prior to contouring to accom- modate presumed overdispersion in the small-scale spatial distribution of the animals (Cassie 1963, McIntyre 1971).

As well as sampling across a single transect, samples of benthic Munida gregaria were taken over large longshore areas of the southeastern South Island shelf twice during this study. The first survey was done over the period 19 Oct 79 to 29 Oct 79 and covered the middle to outer shelf from Nugget Point to Timaru. The second survey was done over the period 20 Feb 80 to 30 Mar 80 and covered the shelf from Quoin Point to Moeraki. Samples from both surveys (except that on 30 Mar 80 ) were obtained with a box dredge with a mouth width of $70 \mathrm{~cm}$ and mesh size of $5 \mathrm{~mm}$. It did not have doors. Doors were not required as both surveys were done when pelagic $M$. gregaria were known to be absent. The dredge was hauled for $5 \mathrm{~min}$ at 2 knots. The samples taken on 30 Mar 80 were obtained with the larger dredge used in the benthic transect survey. Samples were treated and analyzed in the same manner as those of the benthic transect survey.

Morphological change in Munida gregaria cohorts sampled on the seasonal transect was studied by calculating the ratio of carapace length to eyestalk length at various sample dates. Williams (1973) showed that this ratio increases with the length of time an individual has been on the bottom. Values were averaged from the 5 shelf stations and both sexes. Pooling of stations was justified by the lack of difference in morphology for a particular cohort between stations at any one time and pooling of sexes was justified by the only slight differences in growth rates between females and males (Fig. 11).

Fecundity of each Munida gregaria cohort was determined by multiplying the average number of eggs carried by females in the cohort by its abundance across the 5 shelf stations on the date each year when maximum numbers of females were berried (Table 2).

Experiments were done to determine the mortality of $0+$ cohort Munida gregaria when they were held captive with larger individuals from older cohorts. In late November 1981,0+ shoaling juveniles were dipnetted from Otago Harbour and older individuals were dredged from the shelf. Experiments were done in tanks $(110 \times 55 \mathrm{~cm})$ each filled to $12 \mathrm{~cm}$ depth with

Table 2. Munida gregaria. Fecundity data. Mean numbers of eggs carried by females of each cohort at the dates of maximum percentage berried. Data are from all shelf stations pooled

\begin{tabular}{|c|c|c|c|c|c|c|c|c|c|c|c|c|}
\hline \multirow[t]{2}{*}{ Date } & \multicolumn{3}{|c|}{ Cohort 1976} & \multicolumn{3}{|c|}{ Cohort 1977} & \multicolumn{3}{|c|}{ Cohort 1978} & \multicolumn{3}{|c|}{ Cohort 1979} \\
\hline & Mean & S.D. & $n$ & Mean & S.D. & $\mathrm{n}$ & Mean & S.D. & $\mathrm{n}$ & Mean & S.D. & $\mathrm{n}$ \\
\hline 8 Aug 78 & 829 & 342 & 65 & 115 & 66 & 23 & - & - & - & - & - & - \\
\hline 21 Jul 79 & 550 & 201 & 10 & 446 & 267 & 26 & 116 & 61 & 31 & - & - & - \\
\hline $7 \mathrm{Jul} 80$ & - & - & - & 793 & 257 & 8 & 139 & 10 & 2 & 80 & 50 & 39 \\
\hline
\end{tabular}


flowing seawater and subdivided into 12 compartments $(18.3 \times 27.5 \mathrm{~cm})$. Each compartment had a substratum of coarse gravel and a piece of bryozoan or a bivalve shell to provide cover. In the experimental tank each compartment was stocked with one $0+$ and one $1+$ or older individual. In a control tank each compartment was stocked with two $0+$ individuals. The $0+$ individuals settled immediately to the walls or bottom of the compartments. The crabs were not fed but were seen to sort detritus from the sediments. The experiment was repeated $2 \mathrm{wk}$ later, this time with the dividing partitions removed. This allowed the crabs to range over the whole tank $(0.5 \mathrm{~m})$ although the average area available to each individual was the same as in the first experiment. Additionally, an identical third tank was stocked with $230+$ individuals and one $1+$ individual.

\section{RESULTS}

\section{Pelagic phase distribution and abundance}

Pelagic Munida gregaria have been observed along the east coast of the South Island from eastern Foveaux Strait to Tasman Bay (Fig. 2) and over the southern Chatham Rise. There have been rare sightings in Stewart Island and Fiordland. Dense concentrations of pelagic $M$. gregaria have been observed in Campbell Island (Bailey \& Sorensen 1962) and Dawbin (1954)

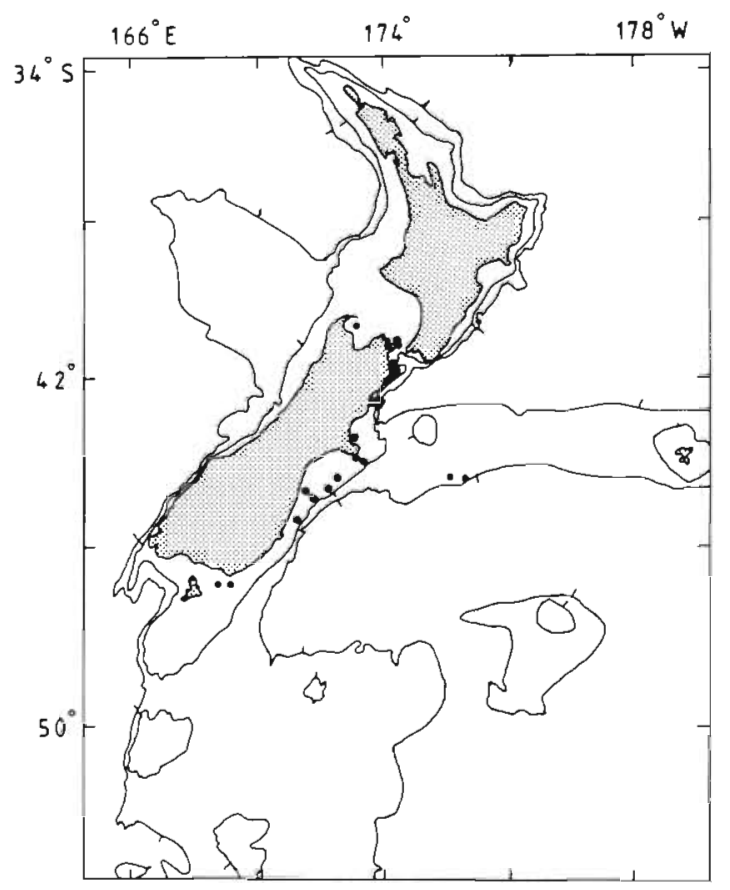

Fig. 2. Munida gregaria. Locations of sightings of pelagic individuals in New Zealand (dots). Data from National Museum, FRD and FMD surveys. Depth contours 250 and $1,000 \mathrm{~m}$

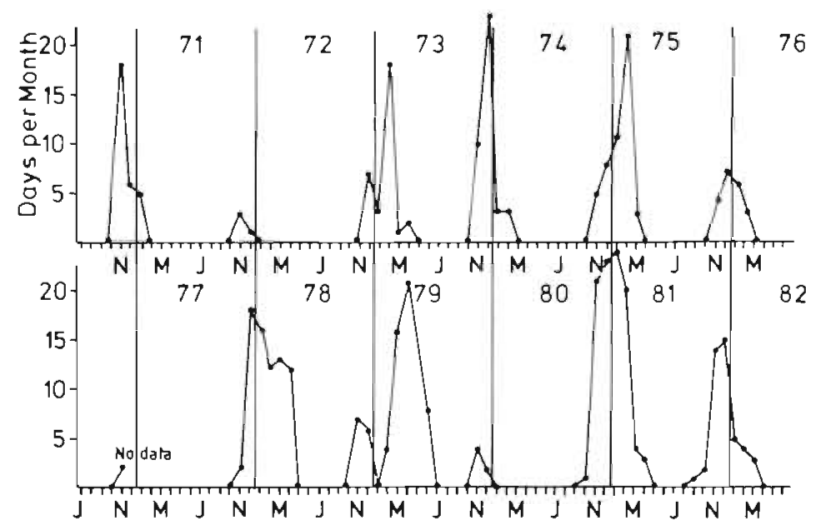

Fig. 3. Munida gregaria. Number of days per month that pelagic postlarvae were seen in the vicinity of PML wharf from Jul 1970 to Jun 1982. N, M and J stand for Nov, Mar and Jul, respectively

found pelagic animals in cormorant faeces and seal and sea lion regurgitations in the Auckland Islands. M. Cawthorn (Fisheries Research Division, Wellington) has also observed Southern Right Whales feeding on M. gregaria at Campbell Island and has observed shoals of $M$. gregaria from November to February at the Auckland Islands.

In the fishermen and lighthouse keeper surveys consistent returns were received from 4 fishermen and 7 lighthouse keepers. In 1979-1980 they reported that postlarval shoals occurred only from November to midJanuary along the south-eastern coast and did not occur in Cook Strait. This was considered by one fisherman to be a 'drastic decrease' compared to the previous year. It also contrasted with the following 1980-1981 season when shoals were consistently reported along the south-eastern coast from November until early April and in small amounts in Cook Strait. The keepers in Foveaux Strait never reported sightings and one had not seen Munida gregaria there in his 10 yr career.

The monthly occurrence of pelagic postlarvae in Otago Harbour in south-eastern New Zealand is shown in Fig. 3 (refer to Williams 1980, for 1953-1970). Postlarvae were most commonly seen in summer, but their occurrence was variable. For example, during 1953 they were seen through the winter. This also occurred in the winter of 1977 (Williams 1980) although wharf observations were not recorded that year. Also, in a number of years, shoaling postlarvae were seen for only a few days over a relatively brief period or not seen at all. A seasonal record for the entire 1953-1981 period (Fig. 4) shows that in 1956-57 and 1967-68 no postlarvae were seen and in four of the seasons postlarvae were not seen after December (e.g. 1971-72, 1979-80).

Plankton samples taken at the PML wharf (Fig. 5) showed that larval production was annual, occurring 


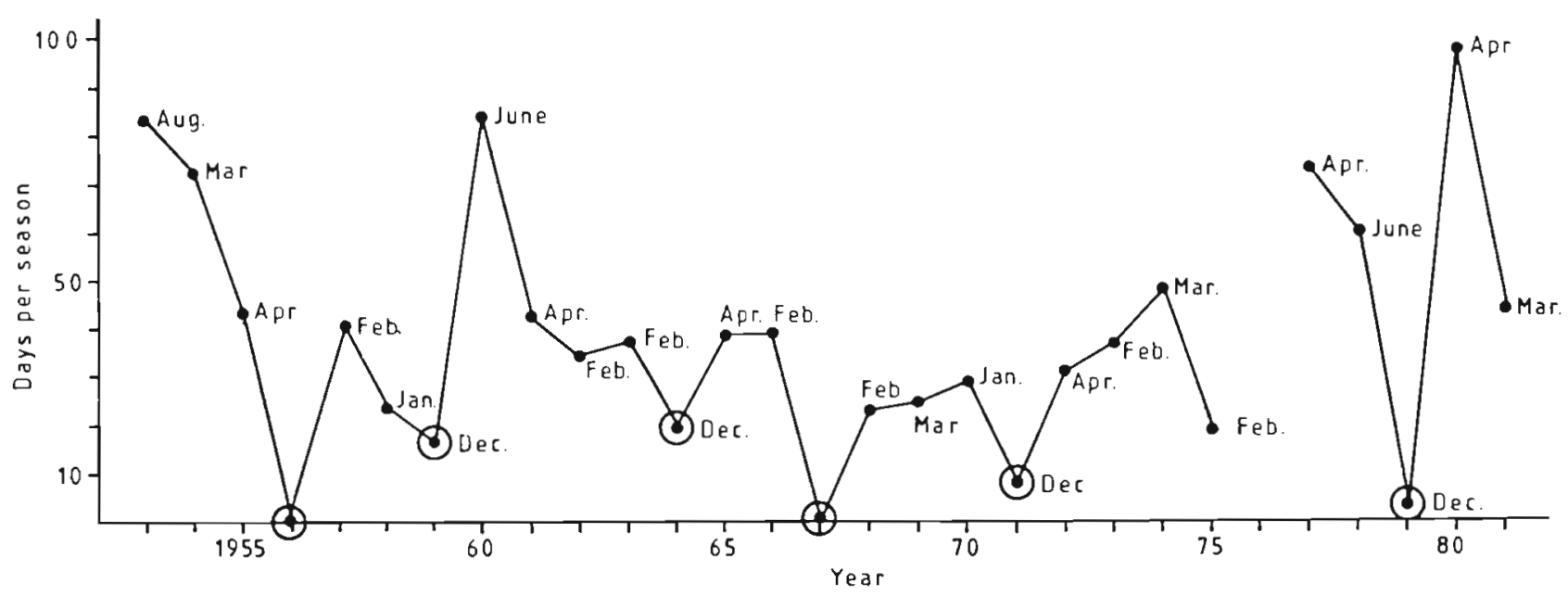

Fig. 4. Number of days per season (Sep-Jun) that postlarvae were observed from PML wharf, 1953-1981. Month given for each year is the last month in which shoaling occurred. Circles: years with short or non-existent shoaling seasons

during late winter and spring. Stage I and II larvae were already present when the first samples were taken each year and usually dominated the catches until late August. Following this, Stages III-V appeared in relatively rapid succession until metamorphosis to the postlarval stage in early to mid-October. The absence of late larval stages in the 1980 survey may have been due to samples being taken too infrequently during late September to record the rapid succession of late stages shown in other years. Older postlarvae $(1+$ cohort $)$ which remained pelagic through the winter (Williams 1980) were caught in November 1977. Considerable numbers of stage 1 zoeae occurred late in some seasons which did not appear as older larvae in subsequent samples, suggesting that they did not develop further. Total catch sizes of old larvae (Stages IV and V) late in most of the larval seasons were as high as the densities of young larvae (Stages I, II) early in the seasons. This does not show the high mortality that planktonic invertebrate larvae normally undergo during development (Mileikovsky 1971) and suggests that the larvae were accumulating at this inshore sampling site. This is also suggested in the August 1971 survey of Robertson (1980) over the broader south-eastern continental shelf (Fig. 6). Stage I larvae were evenly distributed over the area while stages II-V were in higher numbers inshore near Taiaroa Head and Cornish Head than areas south, north and offshore. At this time larvae would have been mainly in stages I-III (Fig. 5). Inshore accumulation of later stage larvae and postlarvae was also shown in the plankton transect surveys across the continental shelf (Fig. 7). On 5 Oct 78 later stage larvae and postlarvae were already common at inner shelf stations (1 and 2) while younger larvae were found mainly in middle shelf stations ( 3 and 4 ). By 18 Oct 78 the inshore larvae had metamorphosed. In the next season older larvae were again caught at inner to middle shelf stations (29 Aug 79) and inner shelf stations (26 Sep 79) with younger larvae at middle shelf stations. By 10 Dec 79 postlarvae predominated inshore. In the 1980 and 1981 seasons early and later season surveys showed similar changes in stage distributions with old larvae inshore and young larvae offshore during peak periods of larval abundance (17 Sep 81).

The distribution of catch sizes (Fig. 8) of postlarvae during all surveys at the grid stations in Blueskin Bay was skewed even after $\log _{10}$ transformation, indicating extreme overdispersion or patchiness over the survey area. This was caused by the frequent occurrence of catches of zero. The geometric mean densities from the individual surveys were all less than 0.50 postlarvae $\cdot \mathrm{m}^{-3}$ and was 0.10 postlarvae $\cdot \mathrm{m}^{-3}$ from the combined data. In contrast, the geometric mean densities of postlarvae caught within shoals by the 2 aimed plankton sampling methods were much higher, being $366 \cdot \mathrm{m}^{-3}$ for the postlarval net and $2,705 \cdot \mathrm{m}^{-3}$ for the metered dip net. These data were also distributed non-normally. After $\log _{10}$ transformation the dip net data were normalized and while there were too few observations made to test the distribution of the transformed postlarval net data, their probability plot appeared linear, suggesting normality. The data therefore conform to the overdispersion model and show that patchiness was also occurring over very fine scales within aggregations of Munida gregaria. Because of reasons given in 'Methods', however, the dip net data were taken as the most accurate for use in aerial survey biomass estimations.

Fig. 9A, B and $\mathrm{C}$ shows the distribution of pelagic postlarval biomass for 3 shoaling seasons along the 
south-eastern coast. In the 1978-1979 season, 2 quantitative flights were done. Biomass was highest in the vicinity of the Waitaki River plume and immediately north of the Otago Peninsula as far as Moeraki. Aggregations were not present south of Taiaroa Head. During 3 previous non-quantitative flights (not figured) on $17 \mathrm{Dec} 78,7 \mathrm{Jan} 79$ and $13 \mathrm{Jan} 79$ only on the December flight were aggregations seen south of Cape Saunders, at the Taeri River. In the $1979-80$ season one flight showed no biomass over the entire flight path. This confirmed results from wharf observations, wharf samples and fishermen and lighthouse keeper surveys that pelagic postlarvae were absent from the southeast coast after early January 1980. In the 1980-1981 season 3 flights showed highest concentrations off Moeraki, the Waitaki River and Timaru. One short flight (not figured) on 3 Mar 82 again showed large aggregations immediately north of the Otago Penin-
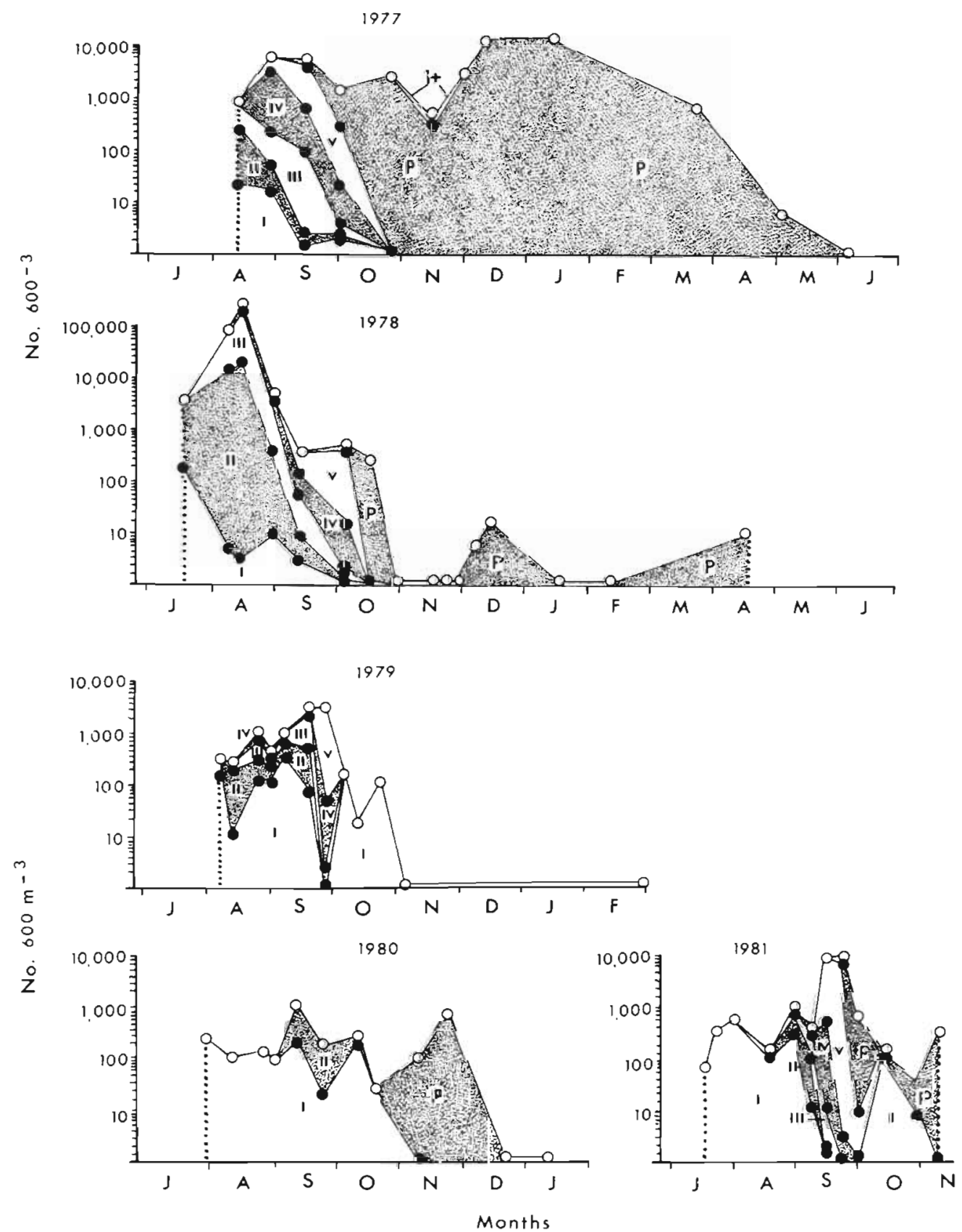

Fig. 5. Munida gregaria. Sizes and compositions of catches of larvae and postlarvae made from the PML wharf 1977 to 1981 Total catch sizes (open circles) refer to logarithmic ordinate. Numbers of each larval stage (I-V) and postlarvae (P) shown as arithmetic proportions made up by shaded and unshaded areas. Small numbers of $1+$ postlarvae also present in 1977 (see text) 

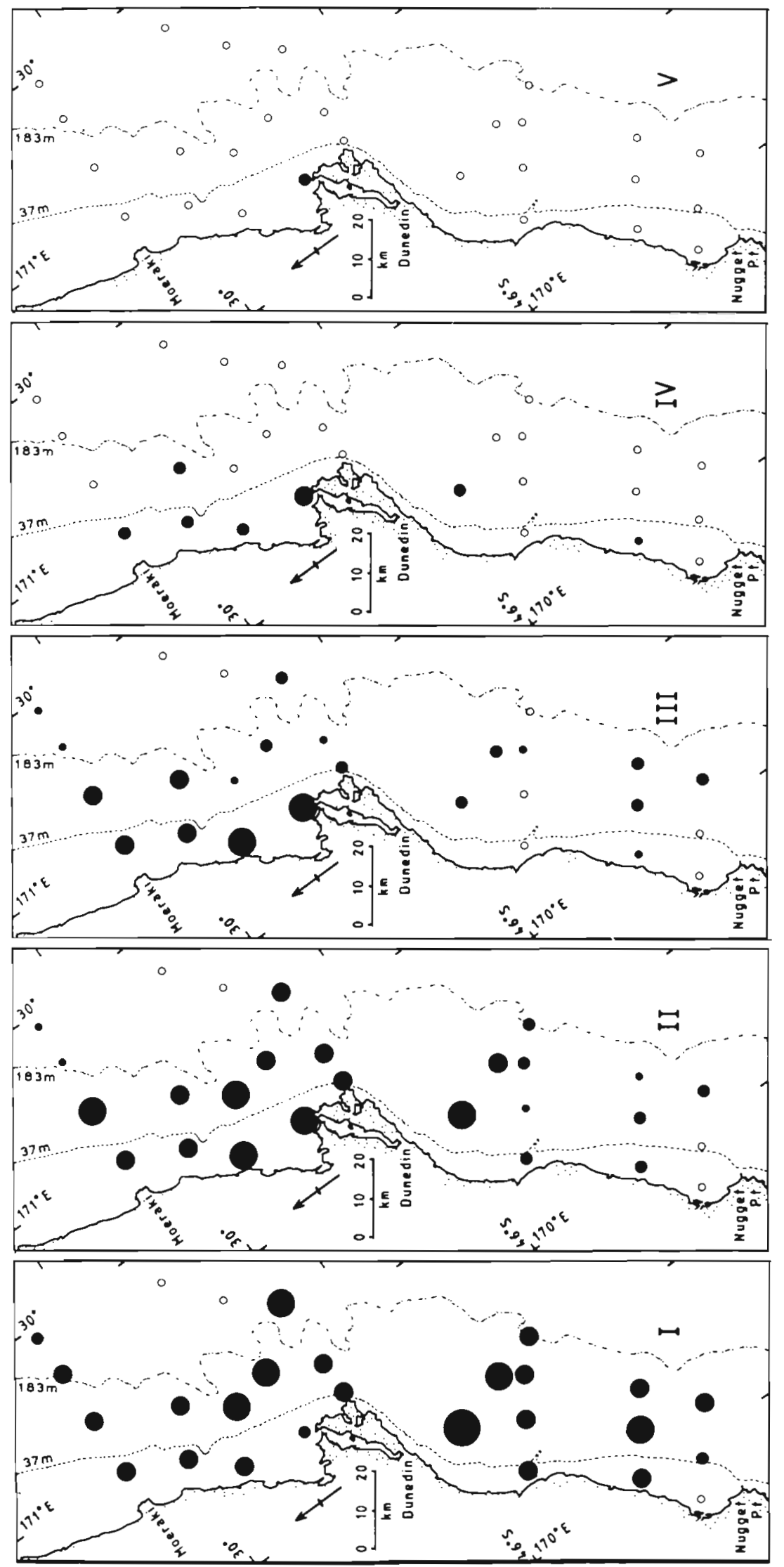

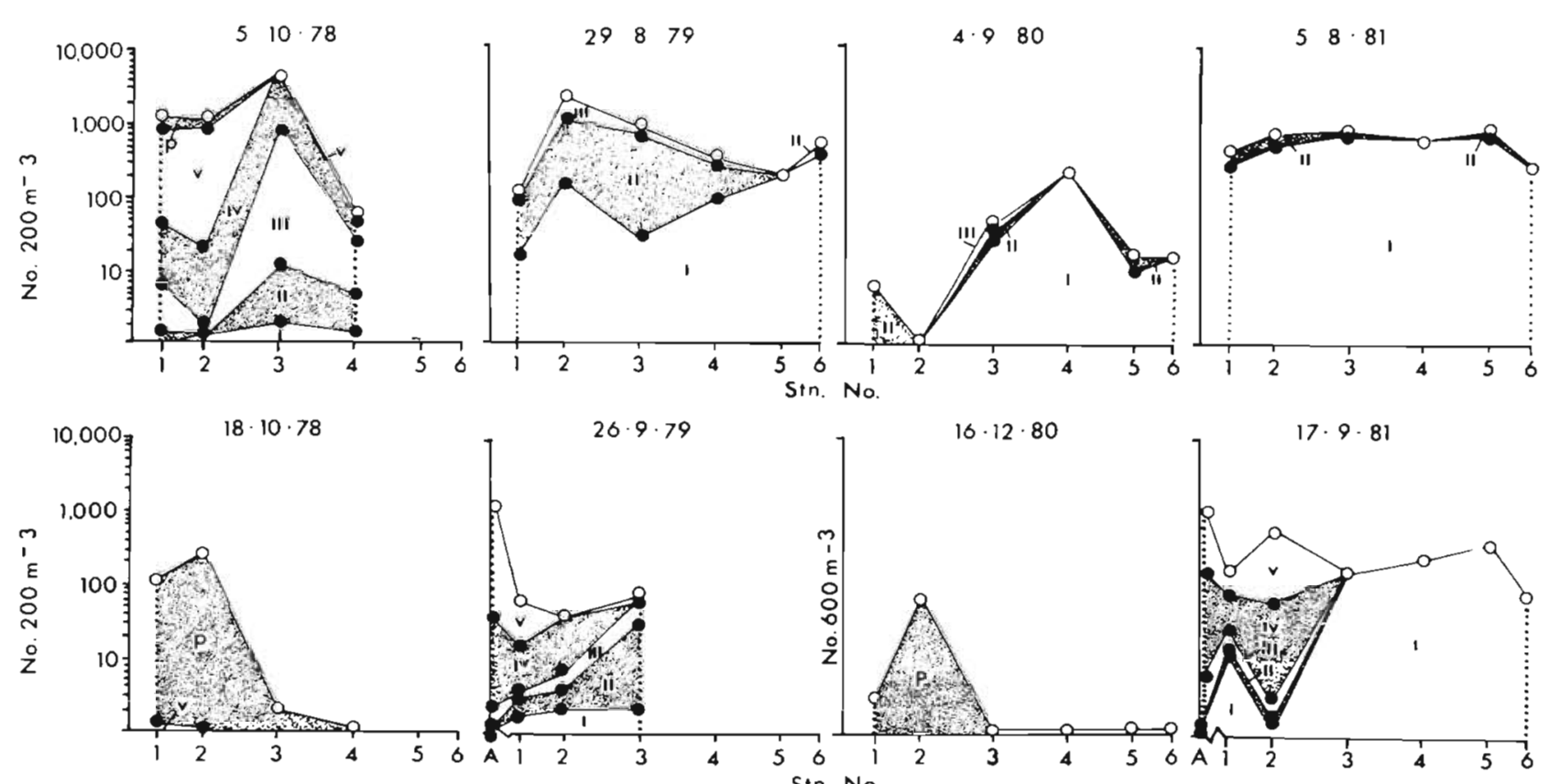

$16 \cdot 12 \cdot 80$
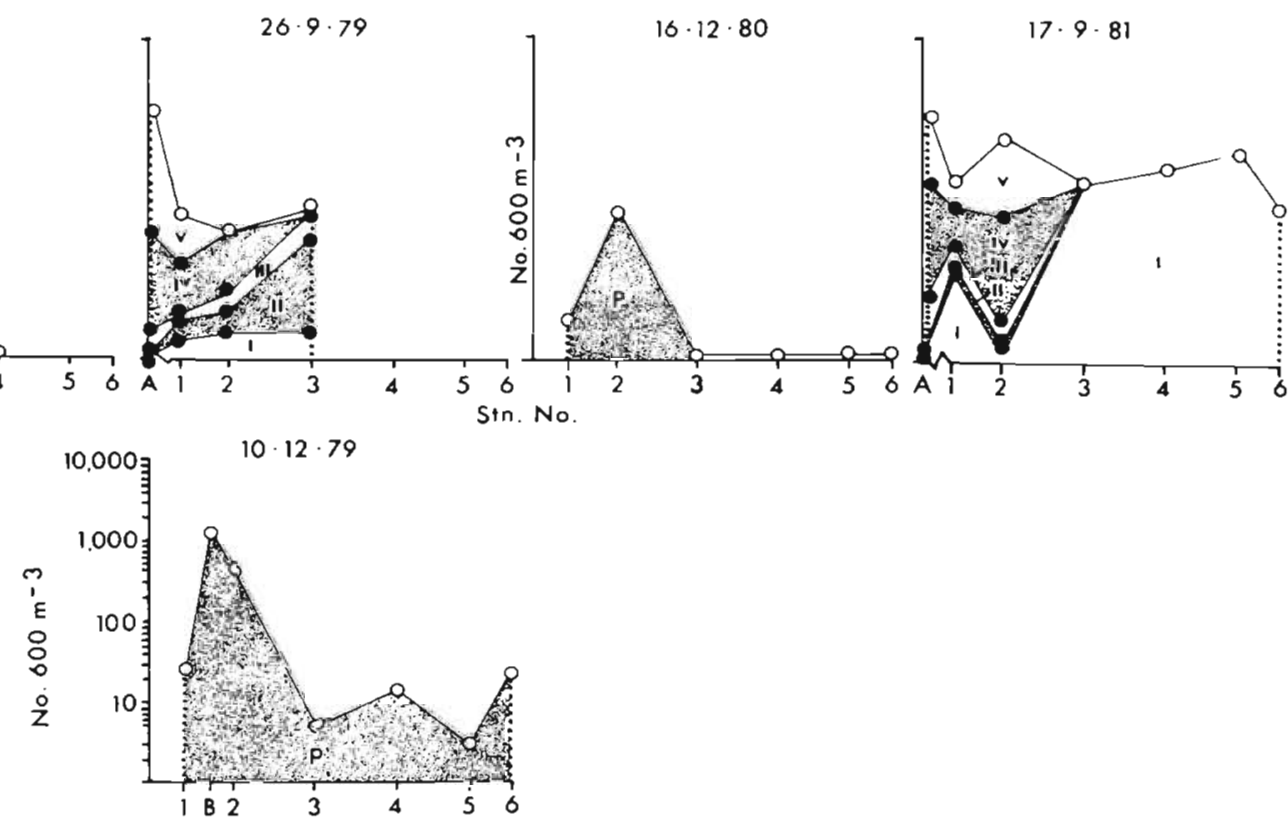

Fig. 7. Munida gregaria. Sizes and compositions of catches of larvae and postlarvae made across continental shelf east of Otago Peninsula 1978-1981. Total catch sizes (open circles) refer to logarithmic ordinate. Numbers of each larval stage (I-V) and postlarvae $(\mathrm{P})$ indicated as arithmetic proportions made up by shaded and unshaded areas. Occasionally additional stations (A and B) were occupied, $1.6 \mathrm{~km}$ inshore of Stn 1 and midway between Stn 1 and 2, respectively. Some offshore stations not occupied on 5 Oct 78,18 Oct 78 and 26 Sep 79
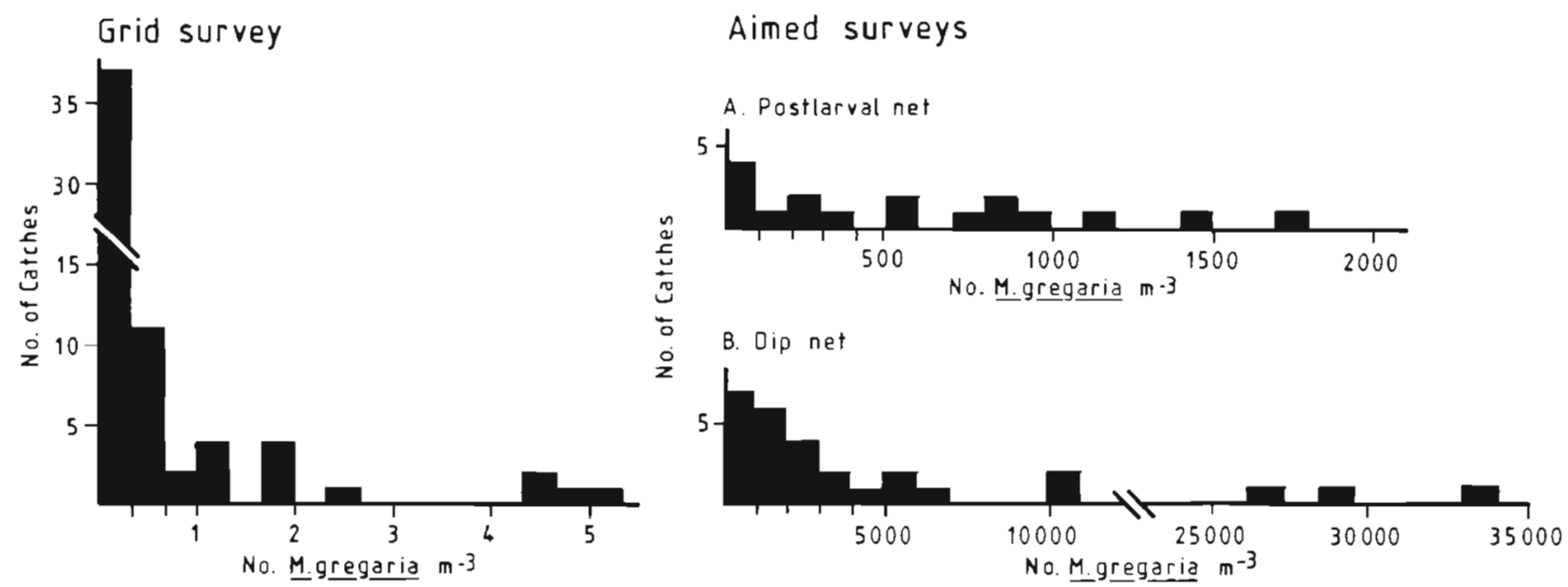

Fig. 8. Munida gregaria. Frequency distributions of pelagic postlarval catch sizes in grid survey and aimed surveys 

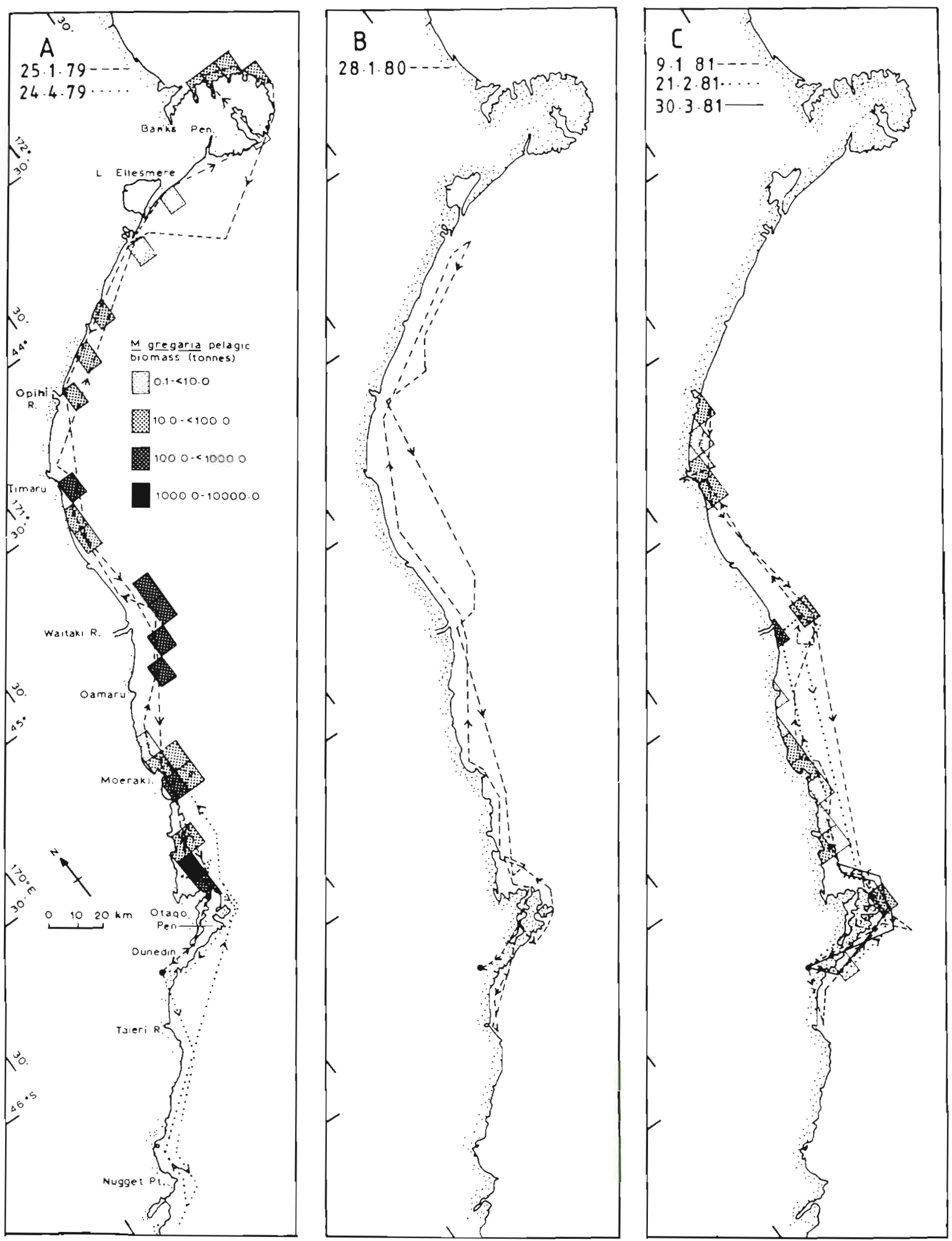

Fig. 9. Munida gregaria. Distribution of biomass of pelagic postlarvae for 3 shoaling seasons along the south-eastern coast. Flight dates and paths for 1978-1979, 1979-1980 and 1980-1981 seasons given on figures 
Table 3. Munida gregaria. Biomass of postlarvae from aerial surveys 1978-1980 seasons compared

\begin{tabular}{|c|c|c|c|c|}
\hline Season & Date & Area surveyed & $\begin{array}{l}\text { Weight } \\
\left(\mathrm{kg} \mathrm{m}^{-3}\right)\end{array}$ & $\begin{array}{l}\text { Biomass } \\
\text { (tonnes) }\end{array}$ \\
\hline \multirow[t]{2}{*}{$1978-1979$} & $\begin{array}{l}25 \text { Jan } 79 \\
24 \text { Apr } 79\end{array}$ & $\begin{array}{l}\text { Taiaroa Head-Opihi River } \\
\text { Taiaroa Head-Just south of Moeraki }\end{array}$ & $\begin{array}{l}1.14 \\
1.51\end{array}$ & $\begin{array}{l}2635 \\
2167 \\
\end{array}$ \\
\hline & & & Total & 4802 \\
\hline \multirow[t]{2}{*}{$1979-1980$} & $28 \operatorname{Jan} 80$ & Taieri River mouth-Lake Ellesmere & - & 0 \\
\hline & & & Total & 0 \\
\hline \multirow[t]{2}{*}{$1980-1981$} & $\begin{array}{r}9 \text { Jan } 81 \\
21 \text { Feb } 81 \\
30 \text { Mar } 81\end{array}$ & $\begin{array}{l}\text { Dunedin-Opihi River } \\
\text { Dunedin-Waitaki River } \\
\text { Dunedin-Blueskin Bay }\end{array}$ & $\begin{array}{l}0.94 \\
1.35 \\
1.39\end{array}$ & $\begin{array}{r}137 \\
236 \\
7 \\
\end{array}$ \\
\hline & & & Total & 380 \\
\hline
\end{tabular}

sula. In all surveys aggregations were always seen within about $12 \mathrm{~km}$ of the coastline. None were seen during filight legs over the middle and outer continental shelf on 17 Dec 78, 25 Jan 79, 24 Apr 79, 28 Jan 80, 9 Jan 81 and 3 Mar 82 .

The biomass of postlarvae photographed in the 1978-1979 season was far greater than in the 1979-1980 and 1980-1981 seasons (Table 3). This is irrespective of the fact that some of the postlarvae from

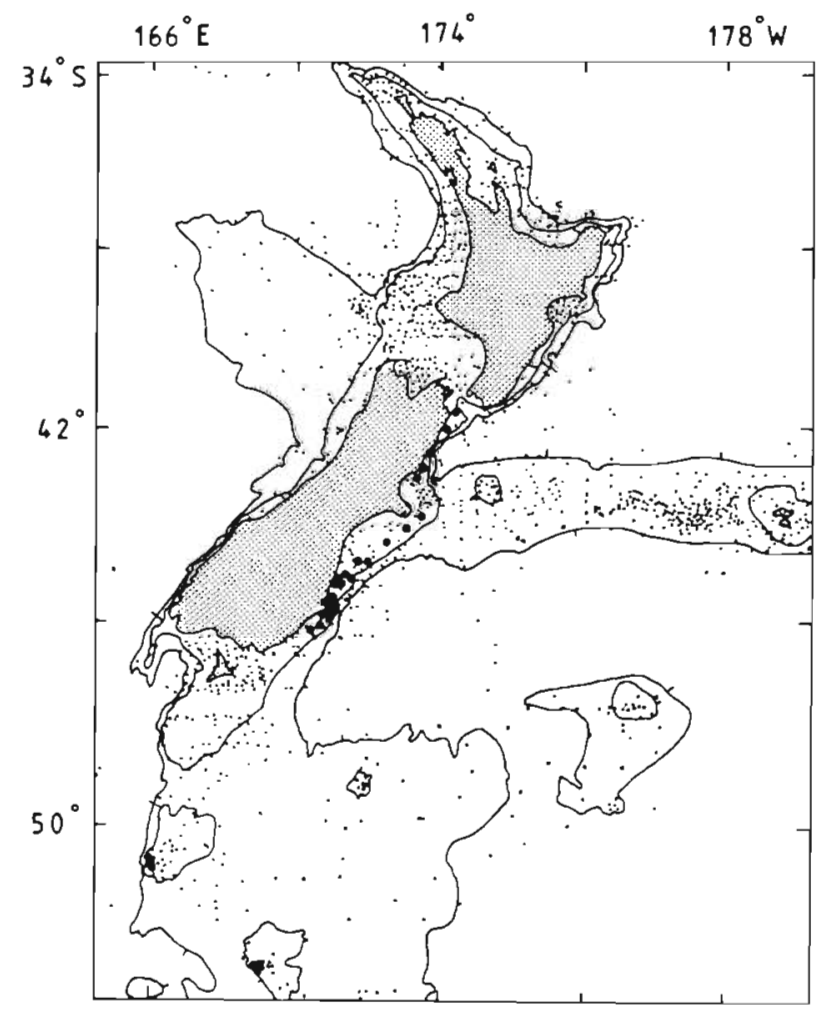

Fig. 10. NZOI and National Museum benthic stations (small dots) and those with Munida gregaria to 1972. Station depictions only approximate in high-density areas. Depth contours $250 \mathrm{~m}$ and $1,000 \mathrm{~m}$. M. gregaria were present at Auckland and Campbell Islands (lower left) the 1980-1981 season were probably counted more than once because of spatial overlap between surveys. There was little overlap between the two 1978-1979 surveys.

\section{Benthic phase distribution and abundance}

Benthic Munida gregaria have been found only along the eastern South Island continental shelf from approximately Nugget Point to Cape Campbell and within harbours and nearshore areas of Auckland and Campbell Islands (Fig. 10). They have also been recorded from the Chatham Islands by Young (1929). Density relative to sampling effort was highest immediately east and north of the Otago Peninsula. The only area shallower than $1,000 \mathrm{~m}$ which was poorly surveyed is the south-western coast of the South Island. No record has been found of benthic $M$. gregaria from this area, although pelagic animals have been observed there on rare occasions (above).

From samples taken on the benthic transect across Otago continental shelf 5 annual cohorts were identified (Fig. 11). These are hereafter referred to the $1976,1977,1978,1979$ and 1980 cohorts, indicating the year in which they were spawned. The precise visual identification of the 1976 cohort was possible due to its unusual morphology. This cohort remained pelagic through the winter of 1977 (Williams 1980) and by November 1977 had grown to a carapace length $\geq 20 \mathrm{~mm}$. They were not seen in surface waters after this. In May 1978 they were dredged in high numbers at the start of this study. They had retained 'pelagic' morphological features. Of the individuals sampled in May 1978, $0.7 \%$ had 'benthic' morphological features and probably belonged to an older cohort (e.g. 1975). These older individuals disappeared from samples by November 1978 and were not considered in size frequency analysis. The $1977-1980$ cohorts were distinguished by size alone. This was difficult when the size 


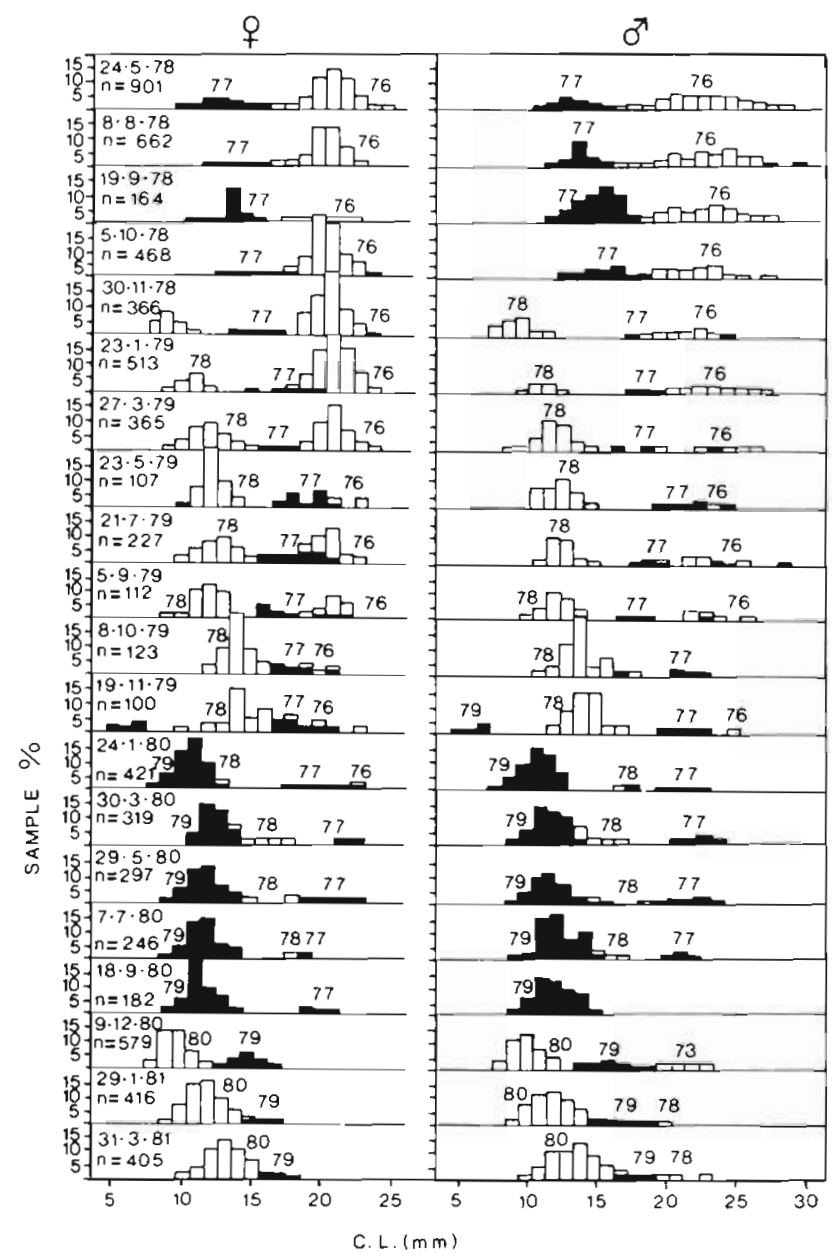

Fig. 11. Munida gregaria. Carapace length frequencies of females and males from benthic transect. Data are from all shelf stations combined on each sampling date. Cohorts spawned in 1976-1980 indicated by black and white bars

distribution of 2 cohorts merged because of decreasing growth rates with age. In some cases, probability paper analysis (Cassie 1954) was used to establish cohort size limits but this was successful on only certain occasions. Some error may therefore have occurred in choosing size limits and determining abundances for the 1977 cohort subsequent to 19 Nov 79 and for the 1978 cohort subsequent to 30 Mar 80.

Contours of the distribution and density of Munida gregaria cohorts across the transect through the study period (Fig. 12) show that the 1977 and 1978 cohort and possibly the 1976 cohort were recruited to the benthos mainly at inner to middle shelf stations 1 to 3 . The centres of maximum density of these cohorts moved from inshore and middle shelf stations to offshore stations within 3 to 9 mo after settlement. The fact that the seaward positions of the contours moved offshore indicated an active migration. The recruitment of the 1979 and 1980 cohorts showed different patterns. For the
1979 cohort recruitment occurred only lightly inshore and was heavy over the middle shelf to upper slope. The 1980 cohort settled heavily at middle shelf as well as inner shelf areas.

Sex ratios showed little variation from unity in time or space for the 1977 to 1980 cohorts. The population of 1976 individuals was dominated by females at the start of the study and remained so until disappearance of the cohort.

Changes in density of benthic Munida gregaria on the seasonal transect resulting from recruitment and mortality were obtained by graphing the numbers in each cohort caught at the 5 shelf stations on the benthic transect against sample date (Fig. 13). The slope station was not used as it was not occupied consistently during the study. Recruitment of the 1979 and 1980 cohorts (the ascending portions of the curves) was observed to be rapid through November and December and peaking in January of 1980 and 1981. In the 1978 cohort the increase was more gradual, peaking in March 1979, showing that recruitment was protracted in that year. Maximum recruit density along the transect also varied between year classes, decreasing from at least $1000 \mathrm{~s}$ in the 1976 cohort to $100 \mathrm{~s}$ in the 1977 cohort and the 1978 cohort. Recruitment of the 1979 cohort was high with 1000 's settling out, as was the recruitment of the 1980 cohort.

Mortality is shown by the descending portions of each curve, the equations for which are given in Table 4 (excluding the 1980 cohort). Analysis of covariance (Wilson 1979) showed that the mortality rates of the 1977-1979 cohorts were not significantly different from each other but were significantly less than the rate of the 1976 cohort by more than a factor of 2 . The mortality rate for the 1976 cohort was calculated from data collected after the time when the crabs were $2+$ years old and there are 2 lines of evidence to suggest that their high mortality rate was due to senescence. First, the 1977 and 1978 cohorts had lower mortality rates than contemporary members of the 1976 cohort, suggesting that predation was not the only reason for the latter's decline. Second, if the curves in Fig. 13 are back-extrapolated using the mortality rates for each cohort to an approximate date of benthic recruitment (Table 5), the densities upon settlement are realistic for the 1977-1979 cohorts, but unrealistically high for the 1976 cohort. This shows that the 1976 cohort could not have sustained such a high mortality rate during its entire benthic existence. It should be noted that the 1976 cohort was delayed in its recruitment by approximately 10 months in 1977 (Williams 1980).

Overall, these patterns of recruitment in conjunction with subsequent migration and mortality had the result that for most of the study period, the Munida gregaria 

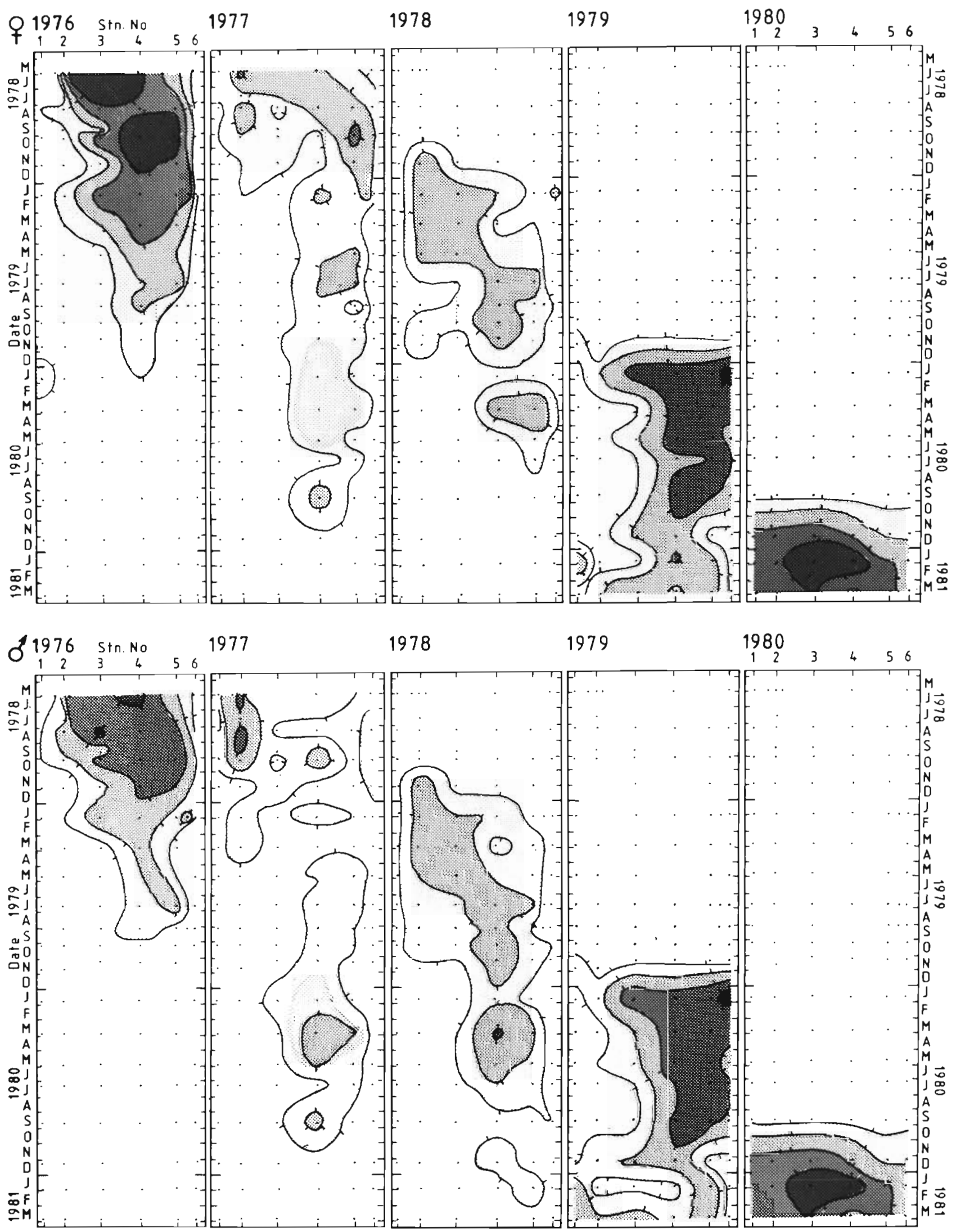

Fig. 12. Munida gregaria. Distribution and density of annual cohorts of females and males across seasonal transect during study period. Density intervals (from light to dark), in number $340 \mathrm{~m}^{-2}$ bottom dredged: 1-9, 10-99, 100-999, 1,000-9,999 


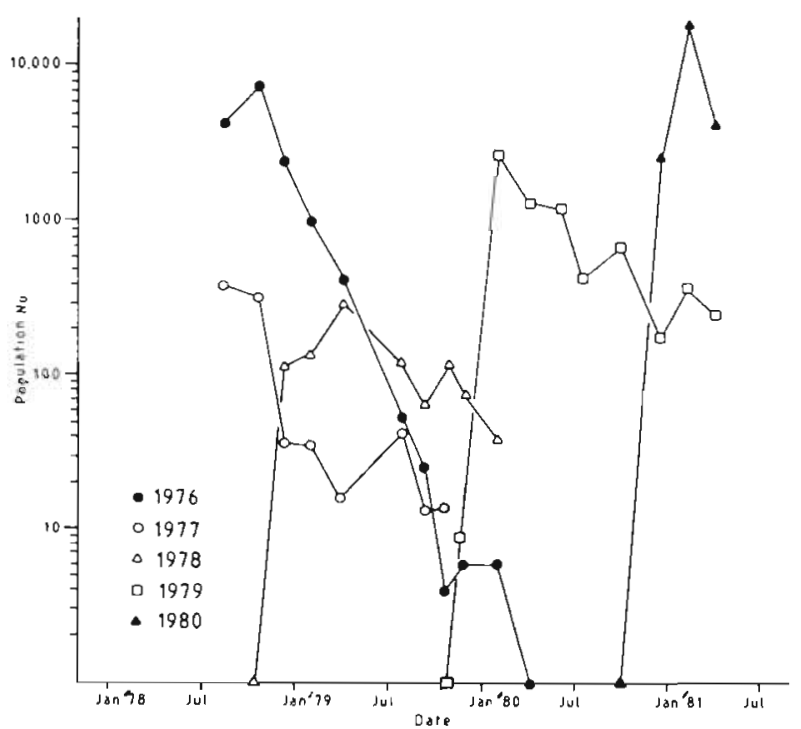

Fig. 13. Munida gregaria. Recruitment and mortality in cohorts of benthic individuals. Each population number is the number of individuals caught at the 5 shelf stations summed for each sampling date. When fewer than 5 stations occupied, values not included (24 May 78, 25 May 79). Values for 1977 cohort from 19 Nov 79 to 18 Sep 80 and for 1978 cohort from $30 \mathrm{Mar} 80$ to $31 \mathrm{Mar} 81$ not included due to inaccuracies in cohort analysis described in text

Table 4. Munida gregaria. Mortality rates of $\ln \mathrm{Y}=\ln \mathrm{A}-\mathrm{Z} \mathrm{B}$; where $\mathrm{Y}=$ population no. $+1 ; \mathrm{A}=$ population no. at approx. day of benthic recruitment $+1 ; Z=$ mortality coefficient; $B=$ no. of days after benthic recruitment

Data from Fig. 13; they begin at sample of maximum abundance for 1978 and 1979 cohorts and at first datum for 1976 and 1977 cohorts. Data for 1980 cohort not analyzed.

$$
\begin{array}{ll}
1976 & \ln Y=19.423-0.01572 \times \mathrm{r}=-0.974 \\
1977 & \ln Y=6.905-0.00613 \times \mathrm{r}=-0.840 \\
1978 & \ln Y=6.653-0.00643 \mathrm{Xr}=-0.926 \\
1979 & \ln Y=7.910-0.00548 \times \mathrm{r}=-0.899
\end{array}
$$

Tests for skewness and kurtosis of variate distribution and non-homogeneity of variance all non-significant.

Analysis of covariance: $\mathrm{F}=18.947$; $\mathrm{P}<0.001$; slopes sig. diff. Using Duncan's New Multiple Range Test: $1977,1978,1979$ slopes insig. diff.; 1976 slope sig. diff.

population along the transect was maintained at levels of $100 \mathrm{~s}$ to $1000 \mathrm{~s}$ at middle and outer shelf stations (Fig. 14). The exception to this was the period July-November 1979 when the population declined to levels of $10^{\prime}$ s. This situation arose through attrition of a population with a 'top heavy' age distribution. By January 1980, the population had re-established itself with a 'bottom heavy' age distribution.

Photographs of the dredge contents showed that the dredged biogenic and lithic material represented the
Table 5. Munida gregaria. Densities on approximate day of benthic recruitment for 1976-1979 cohorts. Calculated from equations in Table 4

\begin{tabular}{|cccr|}
\hline Cohort & $\begin{array}{c}\text { Approx. day of } \\
\text { recruitment }\end{array}$ & $\begin{array}{c}\text { Density } \\
\text { (5 std. hauls) }\end{array}$ & $\begin{array}{c}\text { Density } \\
\mathrm{m}^{-2}\end{array}$ \\
\hline 1976 & 1 Nov 77 & $272.5 \times 10^{6}$ & 161793.0 \\
1977 & 1 Jan 78 & 997.2 & 0.6 \\
1978 & 1 Jan 79 & 775.1 & 0.5 \\
1979 & 1 Jan 80 & 2724.4 & 1.6 \\
\hline
\end{tabular}

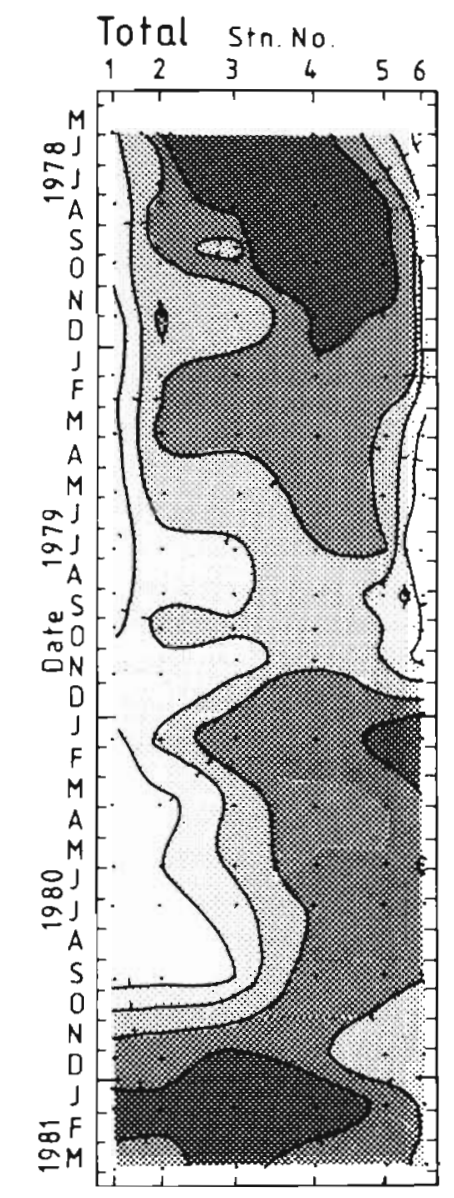

Fig. 14. Munida gregaria Distribution and density of all cohorts and both sexes combined across seasonal transect during study. Density intervals as in Fig. 12

faunal and geological zones identified for the Otago coast by Andrews (1973) and Probert et al. (1979). Briefly, these are an inshore homogeneous sandy area, a middle shelf area of molluscan shell debris, a complex middle to outer shelf bryozoan assemblage and an upper slope molluscan assemblage. Studies by Andrews (1973), Loutit (1976) and Williams (1979) show that these 4 substratum types are distributed along an extensive long-shore section of the southeastern continental shelf north and south of the Otago Peninsula. Table 6 shows the number of times that a particular substratum type appeared at each transect station from 24. May 79 until the end of the study. 
Table 6. Substratum types found at transect stations (see text for details

\begin{tabular}{|ccccccc|}
\hline \multicolumn{1}{c}{ Date } & Stn 1 & Stn 2 & Stn 3 & Stn 4 & Stn5 & Stn6 \\
\hline 24 May 79 & 1 & 2 & 2 & 2 & 4 & 3 \\
21 Jul 79 & 1 & 2 & 2 & 4 & 3 & 4 \\
5 Sep 79 & 1 & 2 & 2 & 3 & 3 & 4 \\
8 Oct 79 & 2 & 2 & 3 & 3 & 3 & 3 \\
19 Nov 79 & 1 & 2 & 2 & 3 & 3 & 4 \\
24 Jan 80 & 1 & 2 & 2 & 3 & 3 & 3 \\
30 Mar 80 & 1 & 2 & 2 & 3 & 3 & - \\
29 May 80 & 1 & 2 & 2 & 3 & 3 & 4 \\
7 Jul 80 & 1 & 1 & 2 & 3 & 3 & 3 \\
18 Sep 80 & 1 & 2 & 2 & 3 & 3 & 3 \\
9 Dec 80 & 1 & 2 & 2 & 2 & 4 & 4 \\
29 Jan 81 & 1 & 2 & 2 & 3 & 3 & 4 \\
31 Mar 81 & 1 & 1 & 2 & 2 & 3 & - \\
\hline
\end{tabular}

Station 1 was nearly always over the homogeneous bottom of the inshore sands. Stations 2 and 3 were nearly always characterized by middle shelf molluscan debris. Stations 4 and 5 were usually over bottoms of high bryozoan abundance although occasionally the outer shelf molluscan substratum was sampled. Station 6 alternated between bryozoan- and molluscan-domi- nated bottoms. Thus, for most of their benthic existence Munida gregaria occupied areas where the bottom was dominated by bryozoans (Fig. 14). The exceptions to this were the periods sometimes spent, in the first few months after settlement, in the sandy inshore areas or in migration across the middle shelf molluscan debris. Station 6 usually had high numbers of $M$. gregaria only if the associated sediments were also high in bryozoans.

In the longshore survey of October 1979 Munida gregaria were found over the entire length of the area surveyed (Fig. 15) but generally in low densities (1 to 99 indiv. standard haul ${ }^{-1}$ ). In contrast, the FebruaryMarch 1980 survey showed much higher densities $\left(10->1,000\right.$ indiv. standard haul $\left.{ }^{-1}\right)$. These high catches were restricted to the area east and north of the Otago Peninsula, apart from two outer shelf stations to the south, and were dominated by the $0+$ (1979) cohort. Also shown are substratum types recovered at these stations. No conclusions regarding substrata $-M$. gregaria associations could be drawn from the low catches of the October 1979 survey. The FebruaryMarch 1980 survey showed that high catches were most commonly associated with bryozoans. This was
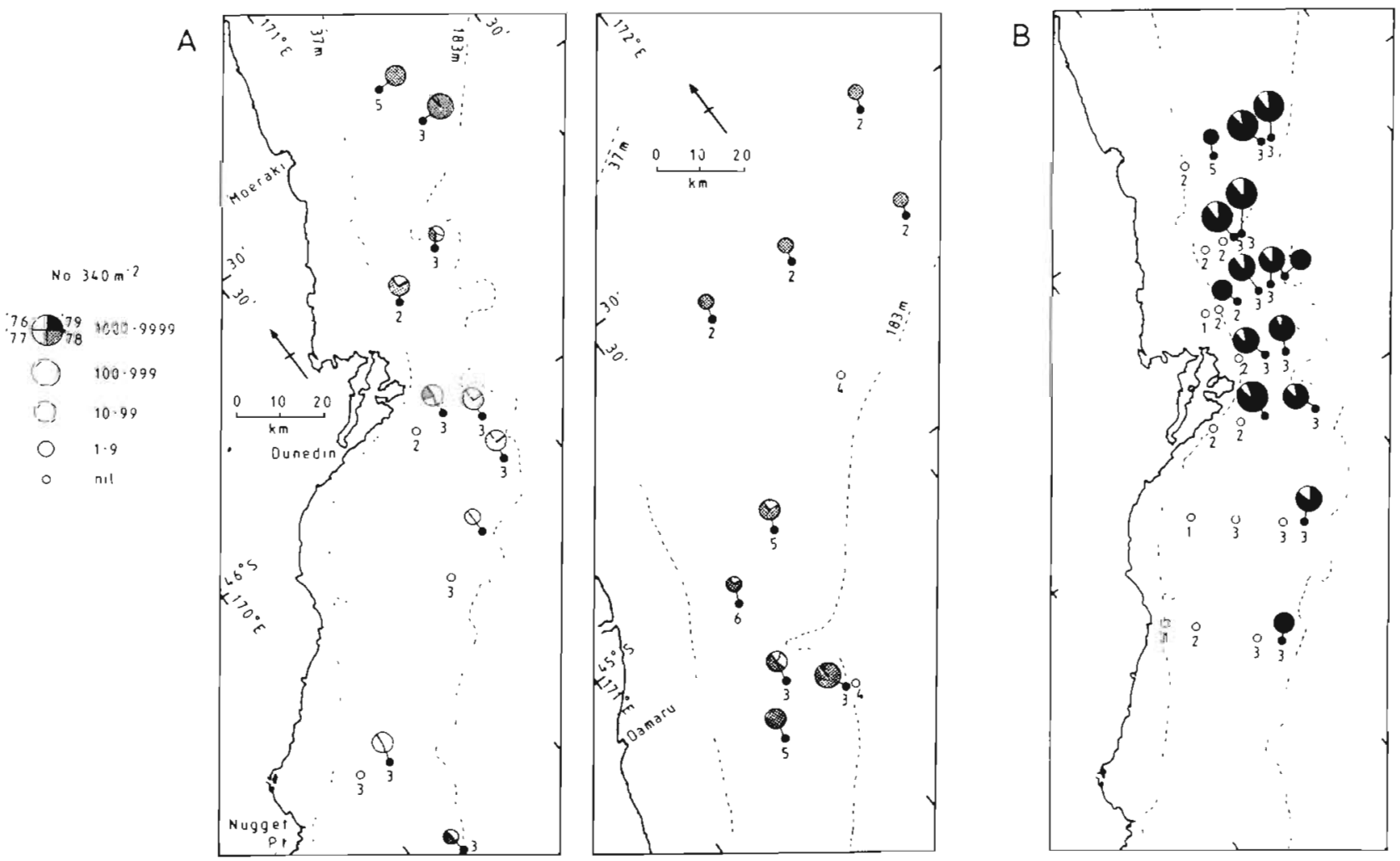

Fig. 15. Munida gregaria. Distribution and density of cohorts from non-seasonal surveys in Oct 1979 (A) and Feb-Mar 1980 (B). Total density per $340 \mathrm{~m}^{2}$ standard haul at each station shown by pie size and numbers in each cohort shown by pie slice sizes. Only 1979 cohort shown in (B), as older cohorts were in low densities only. Numeral at each station refers to substratum type present (see text). Substratum type accidentally not recorded at 1 station in (A) and 2 stations in (B). Types 5 and 6 refer to beds of tube building polychaetes and fine mud, respectively 
Table 7. Munida gregaria. Carapace length to eyestalk length ratios compared between pairs of nearly contemporary benthic and pelagic samples. Stated probability is that means are the same. Last column: proportion of individuals in benthic sample with 'pelagic' morph (i.e. within 2 SD of corresponding pelagic sample mean)

\begin{tabular}{|c|c|c|c|c|c|c|c|c|c|c|c|}
\hline Cohort & Date & $\begin{array}{l}\text { Benthic } \\
\text { mean }\end{array}$ & $\mathrm{SD}$ & $n$ & Date & $\begin{array}{l}\text { Pelagic } \\
\text { mean }\end{array}$ & SD & $\mathrm{n}$ & $\mathrm{t}$ & $\mathrm{P}$ & Proportion \\
\hline \multirow[t]{4}{*}{1978} & 30 Nov 78 & 4.60 & .30 & 30 & 27 Nov 78 & 4.30 & .27 & 30 & 3.17 & $<.01 \quad \mathrm{~S}$ & .83 \\
\hline & $23 \operatorname{Jan} 79$ & 4.85 & .43 & 37 & $15 \operatorname{Dec} 78$ & 4.32 & .34 & 10 & 6.53 & $<.001 \mathrm{~S}$ & .62 \\
\hline & $27 \operatorname{Mar} 79$ & 4.97 & .73 & 73 & 18 Apr 79 & 4.01 & 19 & 10 & 12.22 & $<.001 \mathrm{~S}$ & .18 \\
\hline & 24 May 79 & 5.01 & .56 & 86 & 4 May 79 & 4.11 & .26 & 40 & 9.67 & $<.001 \mathrm{~S}$ & .34 \\
\hline \multirow[t]{2}{*}{1979} & 19 Nov 79 & 4.59 & .71 & 8 & 23 Nov 79 & 4.52 & .31 & 30 & 0.08 & $>.10 \mathrm{NS}$ & .75 \\
\hline & $24 \operatorname{Jan} 80$ & 5.50 & .42 & 126 & $10 \operatorname{Dec} 79$ & 4.56 & .41 & 30 & 35.95 & $<.001 \mathrm{~S}$ & .38 \\
\hline \multirow[t]{3}{*}{1980} & 4 Dec 80 & 5.16 & .38 & 170 & 16 Dec 80 & 4.52 & .30 & 30 & 4.49 & $<.001 \mathrm{~S}$ & .45 \\
\hline & $27 \operatorname{Jan} 81$ & 5.28 & .56 & 187 & 3 Feb 81 & 4.35 & .35 & 30 & 6.45 & $<.001 \mathrm{~S}$ & .37 \\
\hline & 31 Mar 81 & 5.22 & .67 & 167 & 13 Mar 81 & 4.08 & .21 & 30 & 5.30 & $<.001 \mathrm{~S}$ & .20 \\
\hline
\end{tabular}

not true, however, for 3 stations south of the Otago Peninsula where no $M$. gregaria were caught amongst the bryozoans.

\section{Population dynamics}

As described in the 'Introduction', the tendency of postlarval Munida gregaria to change morphologically after benthic settlement relative to contemporary pelagic animals provides a 'tracer' of the timing of settlement and, hence, the duration of shoaling. This morphological change, as measured by carapace length to eyestalk length ratios, is shown in Table 7. Williams (1980) concluded that once an animal settled to the bottom and moulted it began to assume 'benthic' features and could not become pelagic again. Therefore, these results show that by December or January permanent recruitment of significant numbers of animals to the benthic population had already occurred.

The last column in Table 7 shows the proportion of crabs from the benthic samples that still had 'pelagic' morphology. These individuals had either recently settled or were only temporarily on the bottom. The proportions of these individuals in the samples was highest in November or December and lower later in the summer. A sizeable proportion (34\%) of these individuals still existed late in the season in 1979 , suggesting that recruitment was protracted in the 1978 cohort compared to the 1979 and 1980 cohorts. This is also shown by the wharf observations (Fig. 3) and the recruitment portion of the benthic population curve for the 1978 cohort (Fig. 13). Additionally, the relative eyestalk lengths from samples of the 1978 cohort in January 1979 were significantly longer than those from samples of the 1979 and 1980 cohorts in January 1980 and January 1981 respectively (Table 8). This suggests earlier overall recruitment of the 1979 and 1980 cohorts than the 1978 cohort. The same significant relation
Table 8. Munida gregaria. Carapace length (L): eyestalk length (EL) ratios compared between 1978, 1979 and 1980 cohorts in January and March of their respective recruitment seasons. Stated probability is that means are the same

\begin{tabular}{|c|c|c|c|c|}
\hline $\begin{array}{c}\text { January } \\
\text { cohort }\end{array}$ & $\begin{array}{l}\text { Date of } \\
\text { sample }\end{array}$ & Mean & $\begin{array}{l}C L: E L \\
\text { SD }\end{array}$ & $\mathrm{n}$ \\
\hline 1978 & $23 \operatorname{Jan} 79$ & 4.89 & .43 & 37 \\
\hline 1979 & 24 Jan 80 & 5.50 & .42 & 126 \\
\hline 1980 & $27 \operatorname{Jan} 81$ & 5.28 & .56 & 187 \\
\hline \multicolumn{5}{|c|}{ Means compared between years: } \\
\hline \multirow{2}{*}{\multicolumn{2}{|c|}{$\begin{array}{l}1978-1979 ; \mathrm{t}=43.48 \\
1978-1980 ; \mathrm{t}=44.22\end{array}$}} & \multirow{2}{*}{\multicolumn{2}{|c|}{$\begin{array}{l}\mathrm{P}<.001 \text {; means sig. diff. } \\
\mathrm{P}<.001 \text {; means sig. diff. }\end{array}$}} & \\
\hline & & & & \\
\hline \multirow{2}{*}{$\begin{array}{l}\text { March } \\
\text { cohort }\end{array}$} & \multirow{2}{*}{$\begin{array}{l}\text { Date of } \\
\text { sample }\end{array}$} & \multirow{2}{*}{\multicolumn{2}{|c|}{$\begin{array}{l}\mathrm{CL}: \mathrm{EL} \\
\mathrm{SD}\end{array}$}} & \\
\hline & & & & $\mathrm{n}$ \\
\hline 1978 & 27 Mar 79 & 4.97 & .73 & 73 \\
\hline 1979 & 30 Mar 80 & 5.45 & .38 & 29 \\
\hline 1980 & 31 Mar 81 & 5.22 & .67 & 167 \\
\hline \multicolumn{5}{|c|}{ Means compared between years: } \\
\hline \multicolumn{2}{|c|}{$1978-1979 ; t=15.27$} & \multirow{2}{*}{\multicolumn{2}{|c|}{$\begin{array}{l}\mathrm{P}<.001 ; \text { means sig. diff. } \\
\mathrm{P}<.02 ; \text { means sig. diff. }\end{array}$}} & \\
\hline $1978-1980$ & $t=2.59$ & & & \\
\hline
\end{tabular}

existed between March samples of each cohort (Table 8).

The stock-recruitment relation indicated by the data collected along the benthic transect and aerial surveys is summarized in Table 9 . Columns 2 and 3 of the table show the pooled numbers of females and males of each cohort found at the 5 shelf stations on each sample date shown in Column 1. Column 4 lists the total catch size. Column 5 shows the total egg production by these females, calculated using cohort fecundities shown in Table 2. Column 6 shows the tonnage of postlarvae photographed in the aerial surveys in each year. Column 7 lists the numbers of $0+$ individuals in the population on each sample date. The values with asterisks are the numbers of new recruits during the recruit- 


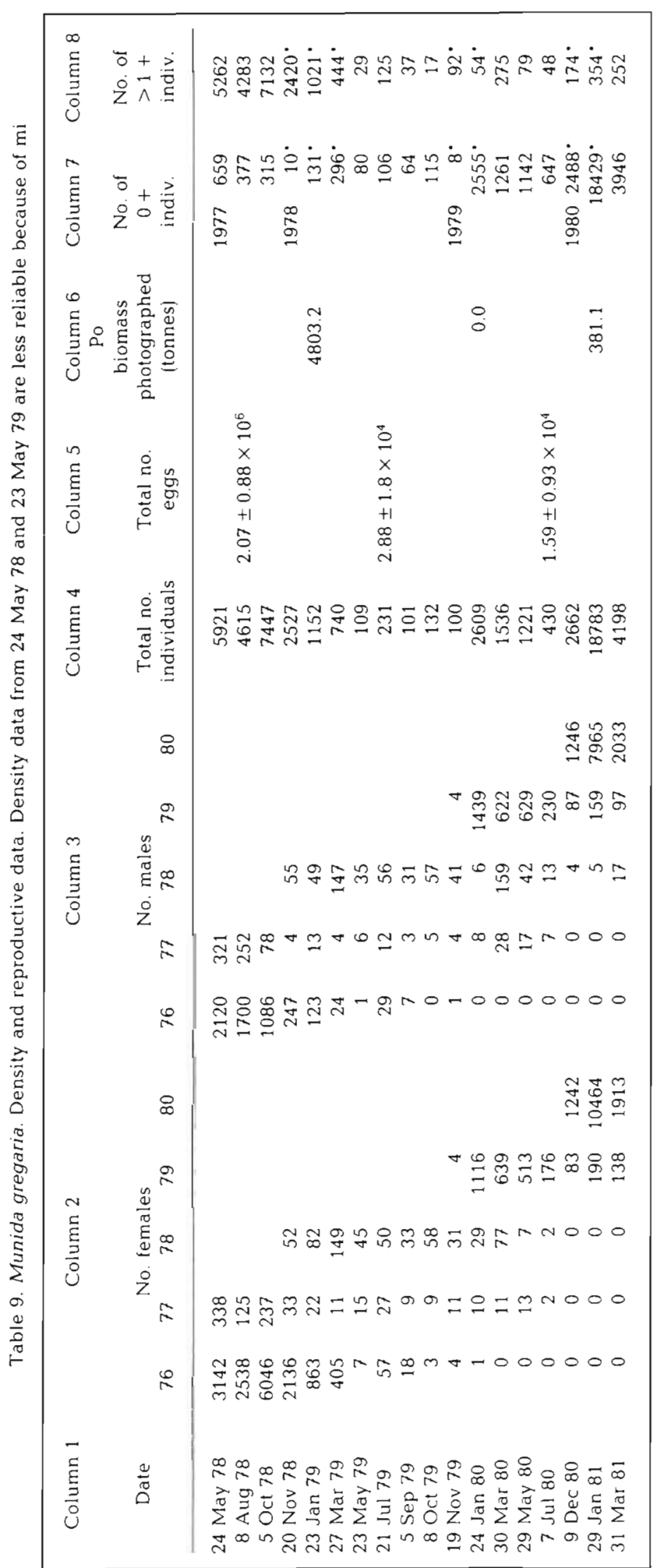


ment period (Fig. 13) for each year. Immediately prior to this period the former $0+$ individuals join the numbers of older individuals in Column 8 . The values with asterisks in Column 8 show the densities of older individuals on the bottom during the recruitment periods. The results of this analysis are as follows: (1) Egg production was a positive function of the number of mature females and their size (the 1976 cohort indiv. were both more abundant and larger than subsequent cohorts). Thus egg production in 1978 was $70 \times$ that in 1979 and $130 \times$ that in 1980. (2) Egg production showed some agreement with the tonnage of pelagic postlarvae photographed. (3) Density of new benthic recruits was inversely related to the photographed biomass of shoaling postlarvae from which they settled. This was probably caused by early settlement from the shoals to the benthos by the 1979 and 1980 cohorts prior to their respective aerial surveys and late settlement by the 1978 cohort after its surveys (Fig. 13; Tables 7 and 8). These results suggest that the higher pelagic postlarval biomass of the 1978 cohort need not be explained only by the larger egg stock that produced it. The 1978 cohort appears to have been relatively more protracted in settlement, making it more accessible by the aerial surveys done from January onwards each year. (4) The density of new benthic recruits was inversely related to the density of older animals already on the bottom.

Evidence that these data were representative of population dynamics over a long area of the southeastern South Island continental shelf is given in the aerial surveys and benthic longshore surveys of this study.

The mortality of $0+$ Munida gregaria when they were confined with larger individuals of older cohorts was high within both cage sizes used in the experiments (Table 10). Their mortality was much lower when the density of large individuals was low or zero. Mortality of large $M$. gregaria was zero during the experiments. It appears that $0+$ mortality was due to cannibalism in that they often disappeared completely overnight or were found partially eaten, or on 2 occasions, being eaten. If not killed, $0+$ individuals often lost legs or chelae. After 6 mo mortality in the control large area cage was $35 \%$.

\section{DISCUSSION}

\section{Distribution and abundance}

Pelagic Munida gregaria postlarvae are found chiefly in continental shelf waters of the South Island east coast and within Cook Strait. M. gregaria larvae were also sampled at Kaikoura by Bradford (1972). The
Table 10. Munida gregaria. Mortality of $0+$ individuals held captive with $1+$ or older specimens

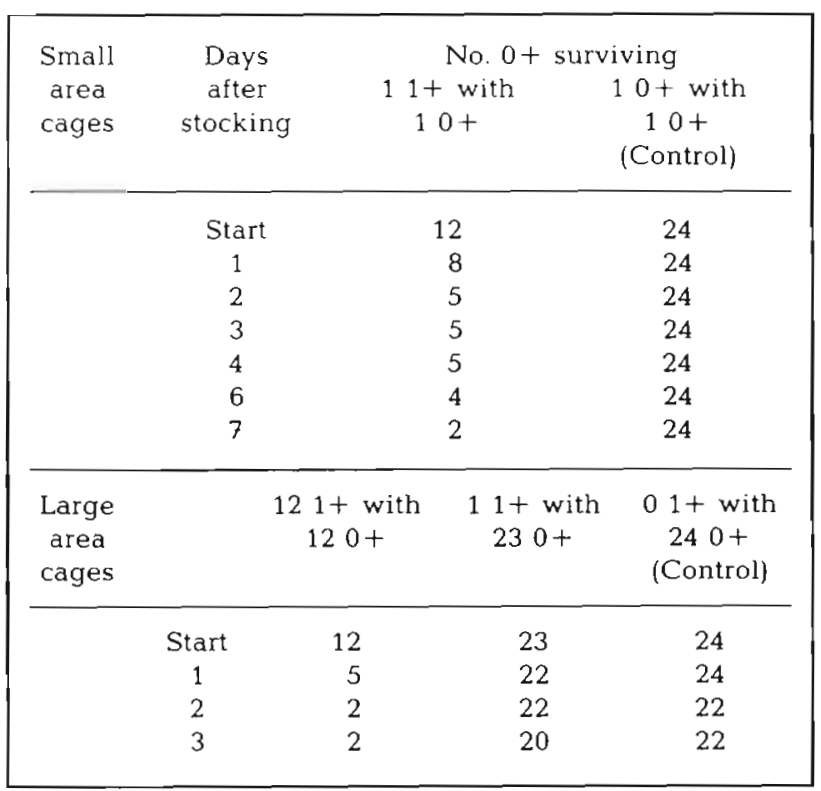

fishermen and lighthouse keeper surveys and aerial surveys support this, at least for the area south of Banks Peninsula. The occurrence of postlarvae south of approximately $46^{\circ} 30^{\prime}$ on the east coast seems very unusual. Postlarval shoals have been observed at Auckland and Campbell Islands and over the Chatham Rise. Benthic M. gregaria are also distributed on the east coast, the Chatham Islands and the subantarctic islands on continental shelf and upper slope areas only, rarely being caught deeper than $250 \mathrm{~m}$.

Along the south-eastern New Zealand coast larvae first appeared in June or July and metamorphosed in early to mid-October. Postlarvae then shoaled during summer and autumn. The larvae first appeared in greatest numbers over the middle to outer shelf, corresponding to the distribution of benthic adults. Older larvae then accumulated over the inner shelf while young larvae persisted offshore. In the samples taken by Robertson larvae became less numerous in the area south of Cape Saunders as they aged but not to the north. This is consistent with transport along this coastline in the northward-flowing Southland Current (Burling 1961, Jillett 1969). The higher inshore densities of Stage II through $\mathrm{V}$ larvae immediately north of the Otago Peninsula, relative to areas south, north and offshore, suggested an accumulation of larvae in the lee of the Peninsula. Accumulation in this area was also suggested by the increasing catch sizes at the PML wharf during most of the larval seasons. Postlarvae were also found mainly inshore in the plankton and aerial surveys and in highest concentrations immediately north of the Otago Peninsula. Simi- 
lar inshore accumulation was also recognized by Roper (1979) who showed that while the spawning distribution of the spider crab Leptomithrax longipes was on the outer continental shelf east of the Otago Peninsula, the newly recruited crabs were found only inshore.

The distributions of pelagic postlarvae over spatial scales of a few metres to a few kilometres were shown by Zeldis \& Jillett (1982) to be determined by the interaction of postlarval behaviour (swarming, taxes) and physical events (e.g. fronts, internal waves) in the water column. The log-normal frequency distributions of catch sizes in the grid surveys of the present study support their observations of highly aggregated shoals from aircraft. Results of the aimed plankton surveys indicated that patchiness within these aggregations was also occurring over scales of only a few metres.

The aerial surveys suggested that the larger (50 to $100 \mathrm{~km}$ ) spatial distributions of postlarvae along the south-east coast were determined by the general hydrology of the area. The large aggregations seen in the area of the Waitaki River plume were probably formed at the frequent physical discontinuities created there by the injection of large amounts of fresh water into a coastal sea already rich in Munida gregaria shoals. The concentrations of larvae and postlarvae at inshore areas north of the Otago Peninsula were probably also due to physical processes. Unpublished temperaturesalinity, current meter and satellite data, some of which appear in Zeldis (1983), indicate that a southward-moving counter-current exists in the lee of the Otago Peninsula inshore of the northward flowing Southland Current. Robertson (1980) described the paths of drift cards released along the coast south of the Otago Peninsula which were recovered in highest numbers on beaches immediately north of the Peninsula and at Moeraki. Robertson also found that the eggs of a number of inshore spawning fish species were retained in this area and not advected north in the Southland Current. Within this area, $M$. gregaria larvae accumulate and, following metamorphosis, shoals of postlarvae are retained for periods of weeks during summer with no apparent replacement from the south, as evidenced by repeated aerial surveys. They are thus kept near the upstream boundary of the benthic stock into which they eventually recruit.

Benthic recruitment of Munida gregaria occurred either at inner and middle shelf stations or at middle and outer shelf stations. In the former case a migration to offshore areas was undertaken within 3 to 9 mo. Migrations in populations of many other decapod species have been observed (Allen 1966, Garcia \& LeReste 1981) which are often in response to reproductive requirements. In the $M$. gregaria population studied here, both sexes generally migrated in equal numbers, suggesting that migration was not solely to reach spawning grounds. $M$. gregaria may migrate into the offshore bryozoan area because it is complex in its micro-relief and supports a rich biota (Probert at al. 1979). It would therefore provide them with protection and a good food supply. However, as shown in the longshore surveys, bryozoans were found over an extensive area of the shelf, including areas to the south of the Peninsula where $M$. gregaria did not recruit heavily. Therefore, the presence of bryozoans may explain the offshore distribution of adults east and north of the Otago Peninsula, but not their higher recruitment there than to the south. The higher density to the north is more likely to be related to the accumulation and retention of larvae and postlarvae in the lee of the Otago Peninsula by counter-current circulation in that area.

Munida gregaria in New Zealand show similar latitudinal and seasonal distributions to the South American M. gregaria populations (Matthews 1932, Rayner 1935). They differ, however, from Mexican Pleuroncodes planipes which are mainly subtropical and may have postlarval seasons lasting up to $2 \mathrm{yr}$ (Longhurst 1967b). In common with all these populations, however, is that their larvae, postlarvae and adults are mainly found close to land, over the continental shelf (Matthews 1932, Rayner 1935, Tabeta \& Kanamaru 1970, Longhurst 1967b, 1968). Longhurst (1967b) showed that the largest catches of postlarvae, which he presumed represented dense surface concentrations, were situated mainly within the influence of the major capes of Baja California. Kato (1974) also found massive concentrations in Bahia Magdalena, immediately south of Cape San Lazaro. The retention of $P$. planipes during its long pelagic existence over the continental shelf was considered by Longhurst to be made possible by eddy flow inshore of the southerly drift of the California Current. This was formerly proposed by Johnson (1960) to retain larvae of the spiny lobster Panulirus interruptus along this coastline.

\section{Population dynamics}

The plankton samples and observations from the PML wharf and the aerial surveys done over 3 shoaling seasons from 1978 to 1981 showed considerable variability in the duration of shoaling by postlarvae between years. For example, the 1976 cohort Munida gregaria persisted in the water column through their first winter, finally settling to the bottom, thereafter retaining 'pelagic' morphological features. In 1979 and 1980, however, benthic recruitment was earlier and heavier over the middle to outer shelf than in previous years. This coincided with low densities of adults on the middle to outer shelf, suggesting that some form of 
density dependent regulation of population size was occurring. Guts of $1+$ and $2+$ benthic individuals collected in March 1979 (during the weak recruitment period of the 1978 cohort) contained a high proportion of crustacean carapace remains, some of which was from $M$. gregaria. Cannibalism could, therefore, have contributed to low recruitment by the 1978 cohort. On the other hand, the fact that 'pelagic' morphs were frequently caught on the bottom in summer suggests that shoaling animals periodically settle to the bottom. If a bottom with low adult density is found, these individuals may settle permanently. If adult density is high, however, they might return to the water column. and prolong their shoaling period. This mechanism would explain both the more 'pelagic' morphology of the 1978 cohort and the longer shoaling season of that cohort observed in the wharf observations and aerial surveys. It also explains the periodic occurrence each 3 to $5 \mathrm{yr}$ of a brief or non-occurring shoaling season (Fig. 4), in which settlement may have occurred early.

Both non-lethal agonistic behaviour and cannibalism have been observed between conspecific decapods. Among stomatopods, Caldwell \& Dingle (1979) reported that size has a significant effect on determining the winner of non-lethal agonistic encounters which result in the maintenance of individual distance (Hazlett 1978). In lobsters, size is again the most important factor determining the outcome of non-lethal encounters (Atema \& Cobb 1980). Crowding, however, can increase the incidence of cannibalism in lobsters (Atema \& Cobb 1980) and freshly moulted animals become especially easy victims. In Munida sarsi, under uncrowded conditions with similar sized individuals, aggressive behaviour is harmless and ensures each individual its private space on which to dig and feed (Berrill 1970). In the present study, aggressive behaviour was lethal to smaller individuals confined with larger individuals under maximal densities observed in the field. $M$. gregaria recruitment could, therefore, have been regulated by both non-lethal agonistic behaviour and cannibalism. A third possibility is that other predatory species may have been in high abundance during November 1978 to March 1979 causing both reduced $M$. gregaria recruitment and the precipitous decline of the 1976 cohort (Fig. 13). This is unlikely, however, as the mortality rate of the 1977 and 1978 cohorts during that period were no higher than in succeeding cohorts.

In this study, recruitment levels varied considerably from year to year, possibly in response to negative effects from older year classes. Giebel \& Heiman (1976), in a study of the ocean shrimp (Pandalus jordani) fishery of California, observed an alternation of strong and weak recruitment years which may have indicated that high numbers of older shrimps have negative effects on the survival of the incoming year class. Off Western Australia, Chittleborough and Phillips (1975) found that the survival of puerulus larvae and early juveniles of the western rock lobster Panulirus longipes on coastal nursery reefs was regulated to nearly constant levels by density dependent effects, mainly competition for food, with older year classes already present. Additionally, Botsford \& Wickman (1978) and Botsford et al. (1983) found that recruitment of $0+$ northern California Dungeness crabs Cancer magister was inversely related to the density of older individuals already present. This was apparently regulated by cannibalism. Stock-recruitment relations for exploited invertebrate species were discussed by Hancock (1973) and density dependent effects were identified for some of these, particularly bivalve molluscs (Vahl 1983). Among crustaceans, however, the relations were often unclear, due chiefly to the absence of long time-series of data and the fact that stock size was frequently assessed only when the animals entered their fishery, usually well after the time they were initially recruited or had become reproductively mature.

\section{Fisheries considerations}

The plasticity in benthic recruitment shown by this Munida gregaria population ensures that the benthic environment is effectively recolonized each year should it be stocked at less than maximum levels. Because mortality of each benthic $0+$ cohort is usually high, this situation often occurs by each spring. However, the numbers of surviving young required to meet this recruitment level is not predictable, which leads in some years (e.g. 1978, 1980) to a surplus of postlarvae above the amount required for the stock to restore its numbers to maximum levels. It would appear that recruitment is largely completed by the end of January each season and that some of the pelagic biomass remaining after that time could be fished. Extensive fishing of postlarvae before the end of January, however, could lower recruit numbers directly and jeopardize the viability of the benthic stock. Also, if fishing at any time were too intensive it could threaten the survival of postlarvae that were not caught, due to a decreased ability to school effectively and enhanced susceptibility to predation (Clark, 1974). If this occurred before the postlarvae settled it could lead to the total failure of a benthic year class in the area.

Biomass potentially available to a fishery opened after January in the Dunedin-Waitaki River area would have been approximately 5,000 tonnes and 400 tonnes wet weight in 1978 and 1980, respectively, bearing in mind the errors possible in these estimates ('Methods'). There would have been no biomass available in 1979 
along the entire South Island east coast because shoaling ceased after January that year. Subsequent shoaling seasons $(1981,1982,1983)$ were longer, apparently similar to the 1978 season, although little quantitative work was carried out. Thus, the biomass available to a fishery could be expected to be variable from year to year and probably non-existent once every 3 to 5 yr.

There is another factor to consider before such a fishery is embarked upon. Munida gregaria postlarvae are very important in the biological economy of the coastal ecosystem both as consumers (Longhurst et al. 1967) and as food for many fish, bird and mammal species ('Introduction'). Removal of postlarvae from an area could be deleterious to the occurrence and survival of these species, unless carefully managed.

Acknowledgements. I thank Dr. B. G. Williams and Dr. J. B. Jillett for their support during this study and acknowledge research grants from the Fisheries Research Division, NZ Ministry of Agriculture and Fisheries and the University of Otago.

\section{LITERATURE CITED}

Allen, J. A. (1966). The rhythms and population dynamics of decapod crustacea. Oceanogr Mar. Biol. A. Rev. 4: $247-265$

Andrews, P. B. (1973). Late Quaternary continental shelf sediments of Otago Peninsula, New Zealand. N.Z. Jl Geol. Geophys. 16 (4): 793-830

Atema, J., Cobb, J. S. (1980). Social behaviour. In: Cobb, J. S. Phillips, B. F. (ed.) The biology and management of lobsters. Academic Press, New York, p. 409-451

Bailey, A. M, Sorensen, J. H. (1962). Subantarctic Campbell Island. Denver Museum of Natural History Proc. 10: 1-305

Benedict, J. E. (1903). Description of a new genus and fortysix new species of Crustacea of the family Galatheidae with a list of known marine species. Proc. U.S. natn. Mus. 26: $243-334$

Berrill, M. (1970). The aggressive behaviour of Munida sarsi (Crustacea: Galatheidae). Sarsia 43: 1-12

Blackburn, M. (1969). Conditions related to upwelling which determine distribution of tropical tunas off western Baja California. Fish. Bull. U.S. 68 (1): 147-176

Blackburn, M., Thorne, R. E. (1974). Composition, biomass and distribution of pelagic nekton in a coastal upwelling area off Baja California, Mexico. Tethys 6 (1-2): 281-290

Boyd, M. (1967). The benthic and pelagic habitats of the red crab, Pleuroncodes planipes. Pacif. Sci. 21 (3): 394-403

Botsford, L. W., Wickham, D. E. (1978). Population cycles caused by inter-age density dependent mortality in young fish and crustaceans. In: Naylor, E., Hartnoll, R. G. (ed.) Cyclic phonema in marine plants and animals. Thirteenth Marine Biological Symposium. Pergamon Press, Oxford, p. 73-82

Botsford, L. W., Method, R. D., Jr., Johnston, W E. (1983). Effort dynamics of the northern Californian Dungeness crab (Cancer magister) fishery. Can. J. Fish. aquat. Res. 40 (3): $337-346$

Bradford, J. M. (1972). Systematics and ecology of New Zealand central east coast plankton sampled at Kaikoura. Bull. N.Z. Dep. scient. ind. Res. 207: 1-87

Brough, J. (1979). Macrozooplankton of Otago Harbour sur- face waters. Portobello Marine Laboratory, University of Otago, Dunedin

Burling, E. W. (1961). Hydrology of circumpolar waters south of New Zealand. Bull. N.Z. Dep. scient. ind. Res. 143: 1-66

Caldwell, R. L., Dingle, J. (1979). The influence of size differential on agonistic encounters in the mantis shrimp, Gonodactylus viridis. Behaviour 69: 255-264

Cassie, R. M. (1954). Some uses of probability paper in the analysis of size frequency distribution. Aust. J. mar. Freshwat. Res. 5 (3): 513-522

Cassie, R. M. (1963). Microdistribution of plankton. Oceanogr. Mar. Biol. A. Rev. 1: 223-252

Castilla, J. C., Becerra, R (1976). The shellfisheries of Chile: an analysis of the statistics (1960-73). In: Valle, L. J. C. (ed.) International Symposium Coastal Upwelling Proceedings. Fundacion Chile, Santiago, p. 50-75

Chittleborough, R. G., Phillips, B. F. (1975). Fluctuations of year class strength and recruitment of the western rock lobster Panulirus lingipes (Milne Edwards). Aust. J. mar. Freshwat. Res. 26: 317-318

Clark, C. W. (1974). Possible effects of schooling on the dynamics of exploited fish populations. J. Cons. perm. int. Explor. Mer 36 (1): 7-14

Dawbin, W. H. (1954). Subantarctic marine food cycles and their relation to discontinuous plankton concentrations. Proc. N.Z. ecol. Soc. 11: 19-20

Garcia, S., Le Reste, L. (1981). Life cycles, dynamics, exploitation and management of coastal penaeid shrimp stocks. F.A.O. Fish. Tech. Pap. 203: 1-215

Giebel, J. J., Heimann, R. F. G. (1976). Assessment of ocean shrimp management in California resulting from widely fluctuating recruitment. Calif. Fish. Game 62 (4): 225-273

Hancock, D. A. (1973). The relationship between stock and recruitment in exploited invertebrates. In: Parrish, B. B. (ed.) Fish stocks and recruitment. Rapp. P.-v. Réun. Cons. int. Explor. Mer 164

Hazlett, B. A. (1978). Individual distance in Crustacea II. The mantis shrimp Gonodactylus oerstedii. Mar. Behav. Physiol. 5: 243-254

Henderson, J. R. (1888). Report on the anomura. Rep. scient Results Voyage H.M.S. 'Challenger', Zool. 27: 1-215

Jillett, J. B. (1969). Seasonal hydrology of waters of the Otago Peninsula, south-eastern New Zealand. N.Z. Jl mar. Freshwat. Res. 3 (3) : 349-375

Jillett, J. B. (1976). Zooplankton associations off Otago Peninsula, south-eastern New Zealand, related to different water masses. N.Z. Jl mar. Freshwat. Res. 10 (4): 543-557

Johnson, M. W (1960). Production and distribution of larvae of the spiny lobster Panulirus interruptus (Randall) with records on $P$. gracilis Streets. Bull. Scripps Inst. Oceanogr. $7(6): 413-462$

Kato, S. (1974). Development of the pelagic red crab (Galatheidae, Pleuroncodes planipes) fishery in the Western Pacific Ocean. Mar. Fish. Rev. 36 (19): 1-9

Longhurst, A. R. (1967a). The biology of mass occurrences of galatheid crustaceans and their utilization as a fisheries resource. Proc. of the World Scientific Conference on the biology and culture of shrimps and prawns. F.A.O. Fish. Rep. 57: 95-110

Longhurst, A. R. (1967b). The pelagic phase of Pleuroncodes planipes Stimpson (Crustacea, Galatheidae) in the California current. Rep. Calif. coop. oceanic Fish. Invest. 11: $142-154$

Longhurst, A. R. (1968). Distribution of the larvae of Pleuroncodes planipes in the California current. Limnol. Oceanogr 13: 143-155

Longhurst, A. R., Lorenzen, C. J., Thomas, W. H. (1967). The 
role of pelagic crabs in the grazing of phytoplankton off Baja California. Ecology 48 (2): 190-200

Loutit, T S. (1976). Continental shelf sedimentation east of Karitane Pt., east Otago, New Zealand. Unpubl. rep., Department of Geology, University of Otago, Dunedin

Matthews, L. H. (1932). Lobster krill, anomuran Crustacea that are the food of whales. 'Discovery' Rep. 5: 467-484

McIntyre, A. D. (1971). Introduction; design of sampling programs. In: Holme, N. A., McIntyre, A. D. (ed.) Methods for the study of marine benthos. I.B.P. Handbook 16, Blackwell, Oxford and Edinburgh

Mileikovsky, S. A. (1971). Types of larval development in marine bottom invertebrates, their distribution and ecological significance; a re-evaluation. Mar. Biol. 10: $193-213$

Milne Edwards, A. (1891). Crustacea. Mission scientifique du Cape Horn, 1882-3, VI (F): 32-37

Pearson, E. S., Hartley, H. O. (ed.) (1962). Biometrika tables for statisticians, Vol. I. Cambridge University Press, Cambridge

Probert, P. K., Batham, E. J., Wilson, J. B. (1979). Epibenthic macrofauna off south-eastern New Zealand and mid-shelf bryozoan dominance. N.Z. Jl mar. Freshwat. Res. 13 (3) 379-392

Quinn, J. (1978). Hydrology and plankton of Otago Harbour Unpubl. rep., Portobello Marine Laboratory, University of Otago, Dunedin

Rayner, G. W. (1935). The Falkland species of the crustacean genus Munida. 'Discovery' Rep. 10: 209-245

Roberts, P. E. (1973). Larvae of Munida subrugosa (White 1847), from Perseverance Harbour, Campbell Island. J. R. Soc. N.Z. 3 (3) : 393-408

Robertson, D. A. (1980). Hydrology and the quantitative distribution of planktonic eggs of some marine fishes of the Otago coast, south-eastern New Zealand. Fish. Res. Bull. (N.Z.) 21: 1-69

Roper, D. S. (1979). Distribution of the spider crab, Leptomithrax longipes and evidence of bacterially induced feminisation. N.Z. J mar. Freshwat. Res. 13 (2): 303-307

Sokal, R. R., Rohlf, F. J. (1969). Biometry, the principles and practice of statistics in biological research. W. H. Freeman \& Co., San Francisco
Tabeta, O., Kanamaru, S. (1970). On the post larva of Munida gregaria (Crustacea, Galatheidae) in Peñas Bay, Chile, with reference to mass occurrence in 1969. Sci. Bull. Fac. Agric. Kyushv. Univ. 24 (4): 227-230

Thompson, W. F. (1926). The California sardine and the study of the available supply. Fish. Bull. Calif. 11: 7-66

Thomson, G. M. (1898). A revision of the Crustaces Anomura of New Zealand. Trans. N.Z. Inst. 1318: 169-197

Thomson, G. S., Thomson, G. M. (1923). The economic value of 'whale-feed'. N.Z. Jl Sci. Technol. 6 (2): 111-114

Tranter, D. J., Heron, A. C. (1968). Hydrodynamic tests on the prototype net of working party 2. In: Fraser, JH (ed.) Standardization of zooplankton sampling methods at sea. UNESCO monogr. oceanogr. methodol. 2

Vahl, O. (1983). Long-term variations in recruitment of the Iceland scallop, Chlamys islandica from northern Norway. Neth. J. Sea Res. 16: 80-87

Williams, B. G. (1973). The effect of the environment on the morphology of Munida gregaria (Fabricius) (Decapoda, Anomura). Crustaceana 24 (2): 197-210

Williams, B. G. (1980). The pelagic and benthic phases of postmetamorphic Munida gregaria (Fabricius) (Decapoda, Anomura). J. exp. mar. Biol. Ecol. 42: 125-141

Williams, J. J. (1979). Quaternary sedimentation of the north Taieri Bight, Otago continental shelf. Department of Geology, University of Otago, Dunedin

Wilson, J. B. (1979). Teddy Bear technical report T5. University of Otago, Computer Centre

Young, M. (1925). Notes on the habits of whale feed (Munida gregaria). N.Z. Jl Sci. Technol. 7: 318-319

Young, M. (1929). Marine fauna of the Chatham Islands. Trans. N.Z. Inst. 60 (1): 136-166

Zeldis, J. R. (1983). Ecology of Munida gregaria (Fabricius) (Decapoda, Anomura). Ph. D. thesis, University of Otago, Dunedin

Zeldis, J. R., Jillett, J. B. (1982). Aggregation of pelagic Munida gregaria (Fabricius) (Decapoda, Anomura) by coastal fronts and internal waves. J. Plankton Res. 4 (4): 839-857 